\title{
Mammalian prion protein (PrP) forms conformationally different amyloid intracellular aggregates in bacteria
}

Bruno Macedo ${ }^{1,2,3}$, Ricardo Sant'Anna², Susanna Navarro ${ }^{2,4}$, Yraima Cordeiro ${ }^{1 *}$ and Salvador Ventura ${ }^{2,4^{*}}$

\begin{abstract}
Background: An increasing number of proteins are being shown to assemble into amyloid structures that lead to pathological states. Among them, mammalian prions outstand due to their ability to transmit the pathogenic conformation, becoming thus infectious. The structural conversion of the cellular prion protein $\left(\operatorname{Pr} \mathrm{P}^{\mathrm{C}}\right)$, into its misfolded pathogenic form $\left(\mathrm{PrPSC}^{\mathrm{Sc}}\right.$ ) is the central event of prion-driven pathologies. The study of the structural properties of intracellular amyloid aggregates in general and of prion-like ones in particular is a challenging task. In this context, the evidence that the inclusion bodies formed by amyloid proteins in bacteria display amyloid-like structural and functional properties make them a privileged system to model intracellular amyloid aggregation.

Results: Here we provide the first demonstration that recombinant murine PrP and its C-terminal domain (90-231) attain amyloid conformations inside bacteria. Moreover, the inclusions formed by these two PrP proteins display conformational diversity, since they differ in fibril morphology, binding affinity to amyloid dyes, stability, resistance to proteinase $\mathrm{K}$ digestion and neurotoxicity.
\end{abstract}

Conclusions: Overall, our results suggest that modelling PrP amyloid formation in microbial cell factories might open an avenue for a better understanding of the structural features modulating the pathogenic impact of this intriguing protein.

Keywords: Mammalian prions, Protein aggregation, Protein conformation, Inclusion bodies, Amyloids, E. coli

\section{Background}

Protein aggregation is the hallmark of many neurodegenerative diseases, including Alzheimer's (AD), Parkinson's (PD), and the Transmissible Spongiform Encephalopathies (TSEs) [1], also termed prion diseases. The misfolding of a particular protein, i.e., the $\beta$-amyloid peptide $(\mathrm{A} \beta)$ for $\mathrm{AD}, \alpha$-synuclein ( $\alpha$-syn) for PD, and prion protein (PrP) for TSEs can lead to its abnormal accumulation in tissues, which usually comes along with severe cellular damages. Irrespectively of the misfolded protein sequence and structure, protein aggregation usually

\footnotetext{
*Correspondence: yraima@pharma.ufrj.br; salvador.ventura@uab.es ${ }^{1}$ Faculdade de Farmácia, Centro de Ciências da Saúde, Universidade Federal do Rio de Janeiro, Av. Carlos Chagas Filho 373, Bloco B, Subsolo, Sala 17, Rio de Janeiro, RJ 21941-902, Brazil

${ }^{4}$ Departament de Bioquímica i Biologia Molecular, Facultat de Biociències, Universitat Autònoma de Barcelona, 08193 Bellaterra, Spain Full list of author information is available at the end of the article
}

proceeds in a well-organized fashion to form amyloids in these diseases [1]. Amyloid fibrils architecture is characterized by a $\beta$-sheet enriched core, which usually binds to Congo red (CR) and thioflavin-T (Th-T) dyes [2].

TSEs form a group of lethal neurodegenerative disorders, which affect both humans and other mammals [3]. They may manifest as infectious, genetic or sporadic diseases. The structural conversion of the cellular prion protein $\left(\mathrm{PrP}^{\mathrm{C}}\right)$, into its misfolded pathogenic form $\left(\mathrm{PrP}^{\mathrm{Sc}}\right)$ is the central event of these pathologies. $\operatorname{PrP}^{\mathrm{C}}$, which is found anchored to the extracellular membrane of several cell types, has a well-defined structure, with a highly flexible and unstructured $\mathrm{N}$-terminal tail and a globular $\mathrm{C}$-terminal domain composed by three $\alpha$-helices and two short antiparallel $\beta$-strands $[4,5]$ (Fig. 1). Unlike $\operatorname{PrP}^{\mathrm{C}}, \mathrm{PrP}^{\mathrm{Sc}}$ is an insoluble protein, mainly composed by $\beta$-sheet structures, partially resistant to proteolysis, with a high propensity to 


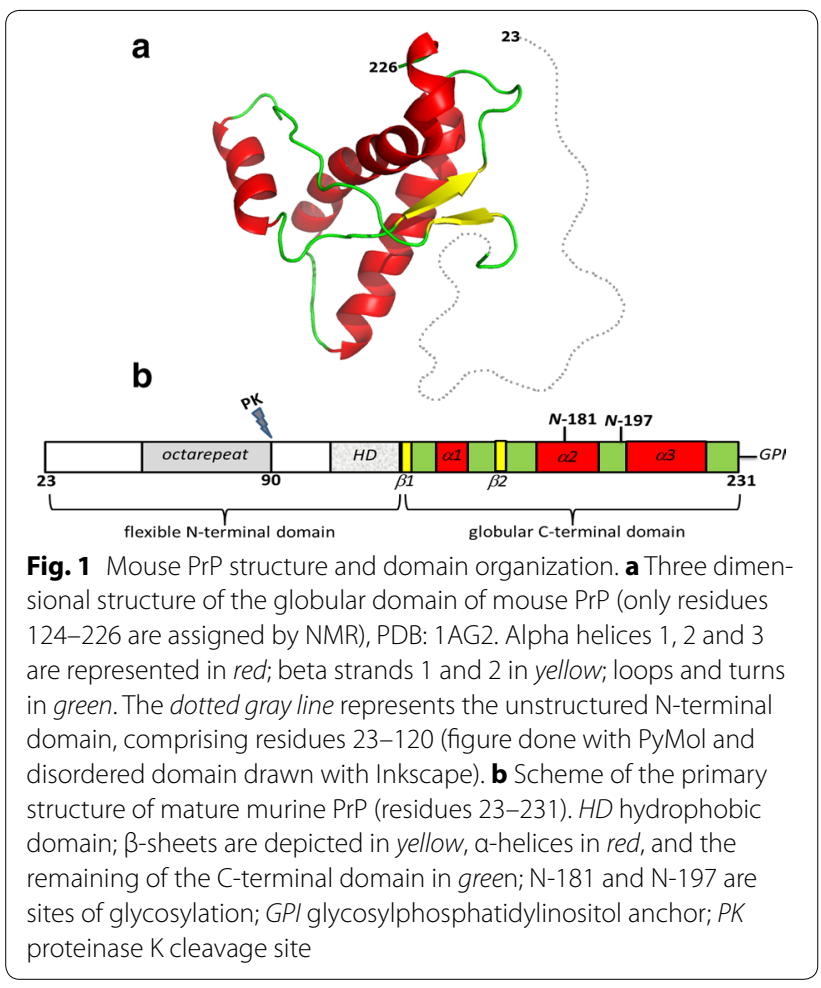

form both amorphous and amyloid-like aggregates [3, 6, 7]. Deposition of aggregated $\operatorname{Pr}^{\mathrm{Sc}}$ in tissues is attributed to cause neurodegeneration. $\mathrm{PrP}^{\mathrm{Sc}}$ aggregation becomes self-perpetuating in vivo through the conversion of host $\operatorname{PrP}^{\mathrm{C}}$ into abnormal $\operatorname{PrP}^{\mathrm{Sc}}$, in a process catalyzed by the infectious form [6, 7]. In vitro, the assembly of prions into amyloids displays a typical nucleation-elongation reaction, but in the presence of preformed fibrillar seeds the 'lagphase', corresponding to the nucleation reaction, is abrogated. The reduction in the lag-phase evidences the ability of the seed to catalyze amyloid polymerization [7-9], a property that underlies the mechanism of prion conformational replication [10]. It is assumed that the PrP can adopt multiple misfolded conformations that are the molecular origin of prion strains and dictate the efficiency of the species barrier in the transmission of prions [11]. Distinct prion strains can lead to phenotypically different prion diseases in animals, with different incubation times and brain deposition profiles [12-14].

Inclusion bodies (IBs) formation in bacteria has long been regarded as an unspecific process resulting from the collapse of hydrophobic contacts between partially or totally unfolded species after protein synthesis at the ribosome [15]. However, an increasing body of evidence indicates that the bacterial IBs formed by amyloidogenic proteins share a number of common structural features with the highly ordered and, in many cases, pathogenic amyloid fibrils [16-19]. Interestingly, it was shown that a specific domain of a bacterial DNA replication protein, the RepAWH1, assembles into fibrils and, when expressed in E. coli, can lead to a peculiar amyloidosis through the inhibition of bacterial proliferation [19]. These RepA-WH1 aggregated particles can be vertically transmitted across generations, thus this protein was characterized as a synthetic bacterial prionoid [19]. Therefore, bacteria have become a simple model system to study intracellular protein aggregation under biologically relevant conditions that cannot be easily recapitulated in vitro, such as the presence of chaperones and proteases, molecular crowding, and the continuous synthesis of the protein in the ribosome [20-22].

Het-s, from the fungus Podospora anserina, was the first prion protein whose bacterial IBs were shown to display amyloid-like properties $[23,24]$. The differential trait of these aggregates emerged when they were transfected into prion-free fungal strains, as they promoted prionic conversion [23]. This result was later corroborated for the yeast prion Sup35 [25, 26]. The amyloid-like IBs of Sup35 induced the prion phenotype in prion-free yeast strains, the infectivity rate being modulated by the environmental conditions during the formation of IBs [25-27]. These observations provide perhaps the best evidence that the IBs molecular structure can recapitulate the architecture of amyloid fibrils, in such a way that even the infectious properties of amyloids, which depend on specific conformational features, seem to be conserved in the two type of aggregates.

It was previously shown that bacterially expressed recombinant murine $\operatorname{PrP}$ can be turned infectious in vitro causing prion pathology when inoculated in mice [28]. Here, we address whether, like their fungal counterparts, mammalian PrP can form amyloid intracellular aggregates when expressed in bacteria. With this aim, we produced, purified and conformationally characterized the intracellular aggregates formed by the wild-type murine $\operatorname{PrP}$ encompassing residues $23-231\left(\operatorname{PrP}^{\mathrm{WT}}\right)$ and the C-terminal domain of murine $\operatorname{PrP}\left(\operatorname{PrP}^{90-231}\right)$ (Fig. 1). Our current study provides the first demonstration that recombinant murine PrPs can form amyloid structures inside bacterial IBs. Besides, although possessing similar secondary structure, PrP ${ }^{\mathrm{WT}}$ IBs and $\operatorname{PrP}^{90-231}$ IBs exhibit conformational diversity, as they bind $\mathrm{CR}$ and Th-T dyes to different extents, display distinct morphology, different stability and resistance against proteinase K proteolysis. These conformational differences result in different toxicity of the two PrP IBs resistant cores when added to neuroblastoma cells in culture.

\section{Results and discussion}

\section{Aggregation of PrPWT and PrP ${ }^{\mathbf{9 0}-231}$ into IBs in bacteria}

The inherent aggregation propensity of amyloid proteins often results in their aggregation into insoluble 
IBs when they are produced in bacteria [29]. In several cases, these intracellular aggregates have been shown to display amyloid-like properties. To verify if this is the case for mammalian prion proteins, we expressed the murine wild-type prion protein $\left(\mathrm{PrP}^{\mathrm{WT}}\right)$ encompassing residues $23-231\left(\mathrm{PrP}^{\mathrm{WT}}\right)$ and the $\mathrm{C}$-terminal domain of murine $\operatorname{PrP}\left(\operatorname{PrP}^{90-231}\right)$ in bacteria and purified the resulting IBs. Both PrP forms [either the fulllength, mature $\operatorname{PrP}\left(\operatorname{PrP}^{\mathrm{WT}}\right)$ or the truncated fragment 90-231] can exist in vivo in healthy and diseased brain and have been extensively studied [30-32]. The N-terminal unstructured domain is proposed to participate in PrP physiological function because of its ability to bind to different classes of partners, including copper ions $\left(\mathrm{Cu}^{2+}\right)$, glycosaminoglycans (GAGs), nucleic acids (NAs) and lipids [33-38]. It is proposed that $\operatorname{PrP}^{\mathrm{C}}$ acts as cell surface scaffold protein, gathering different partners in a macromolecular assembly to participate in cell signalling [39]. $\operatorname{PrP}^{\mathrm{C}}$ undergoes endoproteolytic attack within its $\mathrm{N}$-terminal domain, leading to the appearance of $\mathrm{C}$-terminal fragments attached to the plasma membrane and soluble $\mathrm{N}$-terminal peptides [30]. Both in normal and pathological brains one of these cleavages occurs at position 90, thereby generating $\operatorname{PrP}^{90-231}$ C-terminal fragment. The truncated $\operatorname{PrP}$ encompassing residues 90-231 corresponds to the proteinase K-resistant core of the pathogenic $\mathrm{PrP}^{\mathrm{Sc}}$, referred also as $\mathrm{PrP}^{\text {Res }}$ [30]. Although the $\mathrm{N}$-terminal domain appears to be unnecessary for prion propagation, since the fragment $\mathrm{PrP}^{\text {Res }}$ is capable of transmitting prion disease in vivo [40]; this region may affect the pathways of prion misfolding and substantially impact $\operatorname{PrP}^{\mathrm{Sc}}$ conformational diversity. Furthermore, in vivo studies have shown that mice expressing $\mathrm{N}$-terminally truncated $\operatorname{PrP}$ develop disease more slowly and are less susceptible to infection than mice expressing $\operatorname{PrP}^{\mathrm{WT}}$ [41].

PrP forms were expressed essentially as insoluble proteins in bacteria, with only a small portion of the protein residing in the soluble fraction. Accordingly, IBs were purified from the insoluble cellular fraction (Fig. 2). PrPs were the major component in purified IBs, with $\mathrm{PrP} \mathrm{WT}^{\mathrm{WT}}$ displaying a molecular weight of $\sim 25 \mathrm{kDa}$ and the PrP ${ }^{90-231}$ between 15 and $20 \mathrm{kDa}$, according to respective bands in SDS-PAGE (Fig. 2). The approximate molecular weights obtained from the electrophoresis gel are in accordance with the theoretical molecular masses for both $\operatorname{PrP}{ }^{\mathrm{WT}}$ and $\operatorname{PrP}^{90-231}$ (23 and $16 \mathrm{kDa}$, respectively), with the addition of the histidine-tag $(+\sim 3 \mathrm{kDa})$ (see "Methods"). Further refolding, purification and cleavage steps allowed extraction of soluble and pure PrP from the IBs (see "Methods") for subsequent in vitro fibril formation and seeding analysis.

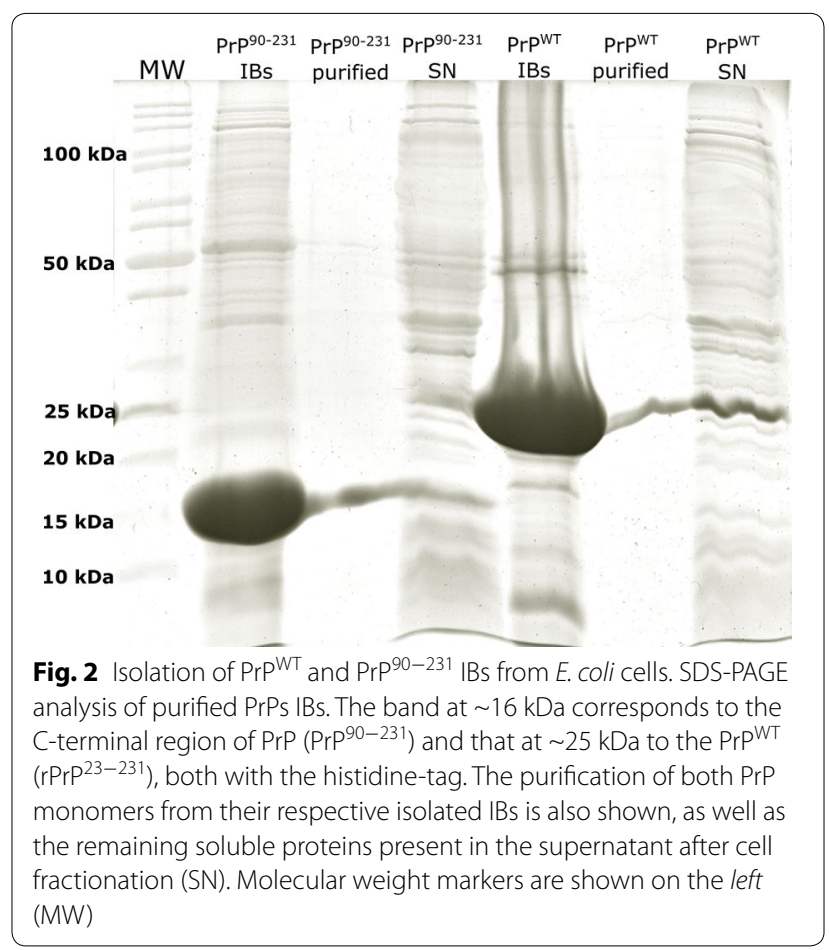

\section{PrP ${ }^{W T}$ and PrP ${ }^{90-231}$ form $\beta$-sheet enriched IBs}

The aggregation of proteins into amyloid fibrils results in the formation of intermolecular $\beta$-sheets $[16,42]$. Attenuated Total Reflectance-Fourier Transform Infrared spectroscopy (ATR-FTIR) permits addressing the structural characteristics of protein aggregates [43-46].

To get insights into the secondary structure content of the two purified PrP IBs, we analysed the amide I region of the FTIR spectrum $\left(1700-1600 \mathrm{~cm}^{-1}\right)$ (Fig. 3). This region corresponds to the absorption of the carbonyl peptide bond group of the protein main chain and is a sensitive marker of the protein secondary structure [47]. Deconvolution of the ATR-FTIR-absorbance spectra of $\mathrm{PrP}^{\mathrm{WT}}$ and $\mathrm{PrP}^{90-231}$ IBs allows us to assign the individual secondary structure elements and their relative contribution to the main absorbance signal (Fig. 3; Table 1). In contrast to soluble purified PrPs, which exhibit a predominant $\alpha$-helical secondary structure content (Additional file 1), as previously assessed by FTIR and circular dichroism [36, 48, 49], it is evident that the truncated form $\left(\operatorname{PrP}^{90-231}\right)$ has a higher contribution of $\beta$-sheets (Fig. 3; Table 1). The low frequency peak at $\sim 1620 \mathrm{~cm}^{-1}$ together with the low intensity, high frequency band at $\sim 1690 \mathrm{~cm}^{-1}$ (band 1, Fig. 3a, b) are attributed to antiparallel beta-sheets found in fibrils [46]. In addition, the peak at $1634-1638 \mathrm{~cm}^{-1}$ (band 4, Fig. 3a, b) found in both IBs is assigned to parallel $\beta$-sheets, indicating a 


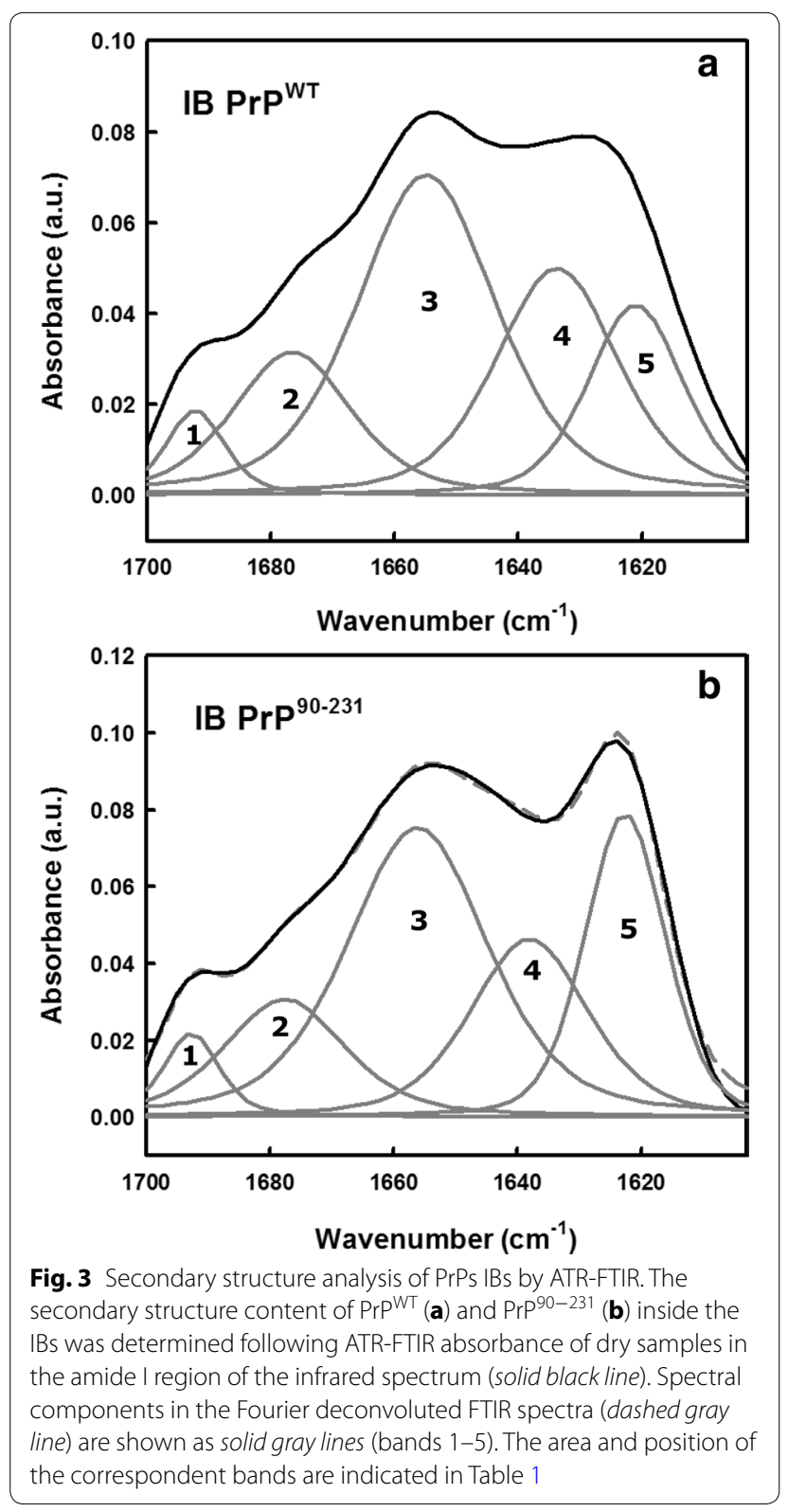

mixed $\beta$-sheet composition for PrPs found in inclusion bodies. In general, the observed absorption FTIR spectra is similar to the one shown for prion rods extracted from scrapie-infected hamster brains [50]. As also seen for infectious prion rods [50], part of the native structure was maintained for both extracted IBs (peaks at $\sim 1655 \mathrm{~cm}^{-1}$ attributed to $\alpha$-helical/disordered structure). Thus, we suggest that a fraction of the molecules are adopting the intrinsic native helical fold, since native protein structure has been described to be retained in the IBs formed by certain proteins, such as GFP and others [51,52].

Amide I ATR-FTIR spectra deconvolution and band assignment was done as described in the Methods section with OMNIC ${ }^{\mathrm{TM}}$ software. Band frequencies deviation: $\pm 4 \mathrm{~cm}^{-1}$. The depicted wavenumbers refer to bands 1-5 (from the higher to the lower frequency) obtained from Fig. 3.

\section{Stability of PrPs IBs towards chemical denaturation}

The presence of regular $\beta$-sheet secondary structure inside PrPs amyloid-like IBs implies the existence of cooperative interactions between the polypeptide chains embedded in these aggregates. To confirm this assumption, we used chemical denaturation with urea. We have shown before that this approach allows approximating the conformational stability of bacterial intracellular aggregates [53]. IBs solubilization was measured by monitoring the changes in absorbance at $350 \mathrm{~nm}$ in urea concentrations ranging from 0 to $8 \mathrm{M}$. The cooperative denaturation transitions observed for both PrPs IBs support the presence of selective contacts inside these aggregates (Fig. 4). We calculated [urea $]_{1 / 2}$ for IBs solubilization to be $3.72 \pm 0.10$ and $2.61 \pm 0.20 \mathrm{M}$, for $\operatorname{PrP}{ }^{\mathrm{WT}}$ and $\operatorname{PrP}^{90-231} \mathrm{IBs}$, respectively; exhibiting thus significantly different conformational stability. The stability of these in vivo formed PrP aggregates is, however, lower than the one reported for in vitro formed $\mathrm{PrP}^{\mathrm{WT}}$ fibrils, with $\mathrm{m}_{1 / 2} \sim 4.5 \mathrm{M}$ in guanidine hydrochloride-induced denaturation experiments [54]. This is not surprising if we take into account that ordered and disordered conformations appear to coexist in IBs and that the presence of minor concentrations of other proteins might also condition the stability of these in vivo formed aggregates.

\section{PrP ${ }^{W T}$ and PrP ${ }^{90-231}$ IBs bind to thioflavin-S in living cells}

We have shown recently that thioflavin-S (Th-S) staining of living bacterial cells can be used to detect the presence of intracellular amyloid-like structures as well as to find inhibitors that interfere with amyloid formation $[55,56]$. The staining of cells expressing $\operatorname{PrP}^{\mathrm{WT}}$ and $\operatorname{PrP} P^{90-231}$ was monitored using fluorescence microscopy. As it can be observed in Fig. 5, induced cells exhibited a green fluorescent background with fluorescent foci located at the cell poles, suggesting that these proteins adopt amyloidlike conformation in bacterial IBs. In contrast, induced cells containing an empty plasmid exhibited only residual fluorescence.

\section{Amyloid properties of PrP ${ }^{W T}$ and PrP ${ }^{90-231} \mathrm{IBS}$}

We evaluated the binding of purified PrP IBs to the amyloid diagnostic dyes CR and Th-T to confirm that the prevalent $\beta$-sheet in these aggregates has an amyloid-like nature and to further explore if the IBs would present different amyloid properties. To evaluate the specific contribution of PrP IBs in these assays, relative to that of other proteins possibly present in this fraction, 
Table 1 Assignment of secondary structure components of purified E. coli PrPWT and PrP ${ }^{90-231}$ IBs in the amide I region of ATR-FTIR spectra

\begin{tabular}{|c|c|c|c|c|c|}
\hline \multicolumn{3}{|l|}{ PrPWT IBs $^{\text {IBS }}$} & \multicolumn{3}{|l|}{$\operatorname{PrP}^{90-231}$ IBs } \\
\hline Band $\left(\mathrm{cm}^{-1}\right)$ & Area (\%) & Secondary structure & Band $\left(\mathrm{cm}^{-1}\right)$ & Area (\%) & Secondary structure \\
\hline 1621 & 16 & $\beta$-Sheet & 1623 & 23 & $\beta$-Sheet \\
\hline 1634 & 25 & $\beta$-Sheet & 1638 & 20 & $\beta$-Sheet \\
\hline 1655 & 40 & Unordered/a-helix & 1656 & 39 & Unordered/a-helix \\
\hline 1677 & 15 & $\beta$-Sheet/turns & 1678 & 14 & $\beta$-Sheet/turns \\
\hline 1692 & 4 & $\beta$-sheet & 1693 & 4.5 & $\beta$-Sheet \\
\hline
\end{tabular}

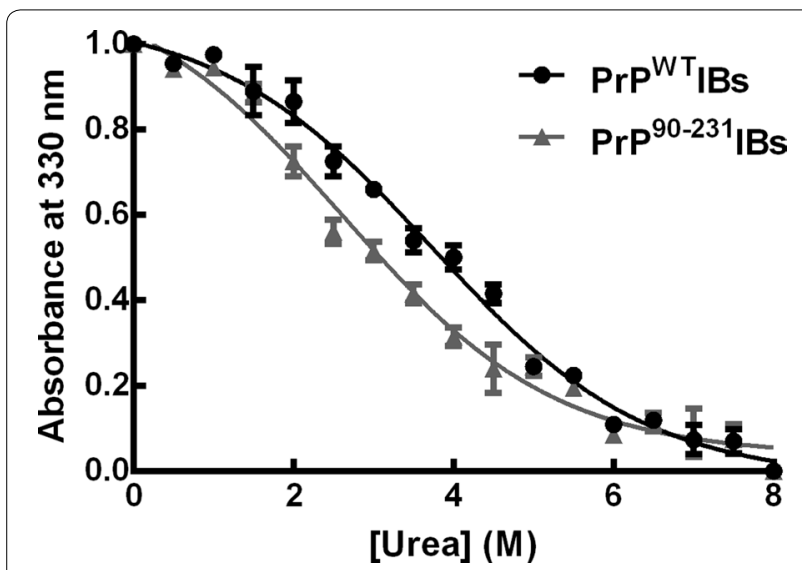

Fig. 4 PrPs IBs present different stability against urea treatment. Solubilization of PrPs IBs $\left(\mathrm{OD}_{350}=1.0\right)$ at equilibrium in the presence of increasing concentrations of urea, monitored by light scattering at $350 \mathrm{~nm}$ at room temperature. Values shown are the mean \pm SD

cells bearing the same plasmid without any insert were induced and the insoluble fraction purified in the same manner than those containing the PrP cDNAs and used as negative control.
The absorbance of CR increases and the spectrum maximum red-shifts in the presence of amyloid-like structures [15]. We calculated the amount of CR bound in relation to the negative control (see "Methods"). We observed a $\sim$ tenfold increase for $\operatorname{PrP}^{\mathrm{WT}}$ IBs and sevenfold increase for $\operatorname{PrP}^{90-231}$ IBs in relation to the control insoluble fraction (Fig. 6a).

ThT fluorescence emission increases significantly when the dye binds to amyloid fibrils [57]. Both PrPs IBs promote a strong increase in Th-T fluorescence (Fig. 6b). In agreement with $\mathrm{CR}$ data, $\mathrm{PrP}^{\mathrm{WT}}$ IBs promote a larger increase in Th-T fluorescence (eightfold) than the promoted by $\operatorname{PrP}^{90-231}$ IBs (3.5-fold), whereas the negative control did not induce any significant increase in fluorescence emission relative to free Th-T (Fig. 6b). Although these two PrP IBs possesses similar secondary structure content, these data indicate that murine $\mathrm{PrP}^{\mathrm{WT}}$ and $\mathrm{PrP}^{90-231}$ adopt amyloid-like structures when they aggregate intracellularly in bacteria, displaying, however, different fibrillar structures. Indeed, it is known that mature fibrils of different PrP species, like hamster or mice, have similar secondary structures but show variation in fibrillar morphology [58].

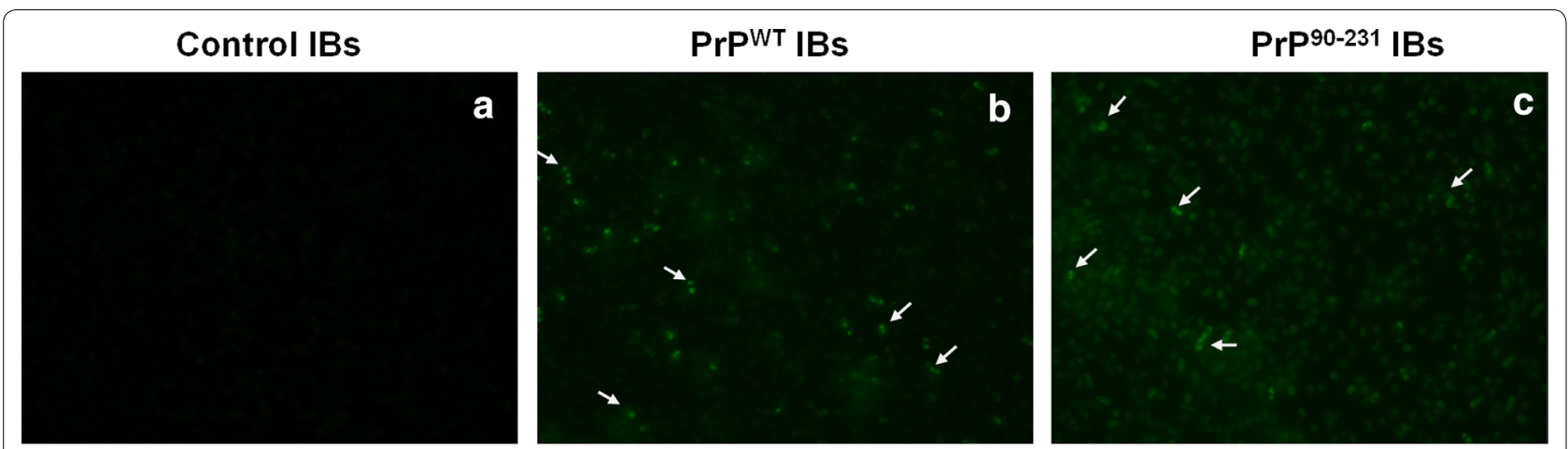

Fig. 5 Th-S staining in intact bacterial cells expressing PrPs. Bacteria expressing recombinant PrPs (b $\operatorname{PrP}^{W T}$; c $\operatorname{PrP}^{90-231}$ ) or containing an empty plasmid (control) (a) were stained with Th-S and observed at $\times 40$ magnification by fluorescence microscopy to visualize the green fluorescence characteristic of amyloid intracellular structures. Arrows indicate the position of IBS 


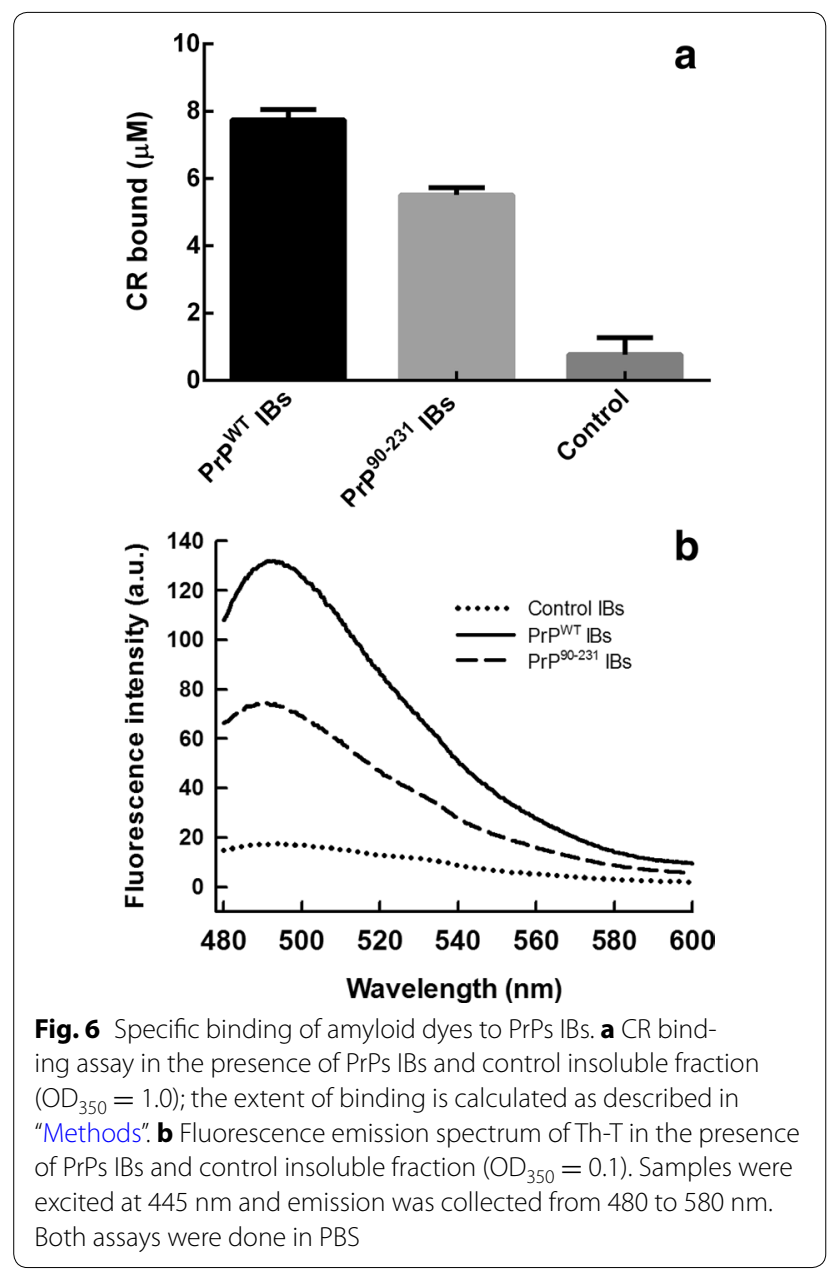

\section{Amyloid morphology of PrPs IBs}

Transmission electron microscopy (TEM) was used to investigate the morphology of $\operatorname{PrP}^{\mathrm{WT}} \mathrm{IBs}$ and $\operatorname{PrP}^{90-231}$ IBs. Interestingly enough, we were able to observe amyloid fibrils in PrP ${ }^{\mathrm{WT}}$ IBs, without any previous treatment with proteases or sonication, coexisting with less ordered aggregates (Fig. 7a, b). For the C-terminal PrP IBs ( $\mathrm{PrP}^{90-}$ ${ }^{231}$ ) we found uniformly shaped aggregates, likely corresponding to prefibrillar structures, similar to aggregates populated upon nucleic acid-induced $\mathrm{PrP}^{\mathrm{WT}}$ aggregation (Fig. 7c, d) [36]. The different morphology of both aggregates fits well with their different stability and binding to amyloid dyes. The amyloid fibrils detected in $\operatorname{PrP}^{\mathrm{WT}}$ IBs show lateral association and display a ribbon-like assembly composed of two or more aligned non-twisted flat filaments (Fig. 7b). These structural features resemble those of in vitro-formed amyloid fibrils by purified recombinant PrPs (see Fig. 8). In addition, we found also single filaments (Fig. 7a, b). This fibrillar disposition is normally found in in vitro-formed $\operatorname{PrP}$ amyloids [59]. The fibrils found in PrPWT IBs possess variable widths and may show some curvature, a feature of ribbon-like assemblies. Some ribbons were observed splitting apart either at their edges or at the middle, evidencing that they were still formed by individual protofibrils (Fig. 7b). We could also observe that some ribbons are associated with each other and form fibrils with a dichotomous pattern, a characteristic well described by Makarava et al. in 2006 for mouse PrP amyloid fibrils formed in vitro [58] (see Figs. 7a, b, 8, 9). This morphology was seen mostly during the nucleation phase of the fibril polymerization and was difficult to find during the subsequent elongation phase. Therefore, we conclude that this morphology represents a stage of early lateral association rather than dissociation of preformed fibrils into protofilaments [58]. In this same work, Makarava et al. showed well distinguishable subsets of fibrils formed by the hamster PrP under identic solvent conditions. It thus suggests that the murine PrP aggregates freely formed inside bacteria in our work can reproduce the same aggregation pathway in vitro without the need of a specific condition, such as buffer, $\mathrm{pH}$, temperature and agitation. This polymorphism within fibrils has been attributed to the variable number of constitutive protofilaments and distinct modes of their lateral association within mature fibrils $[58,60]$. In fact, scrapie fibrils derived from animals with prions diseases were also found to display high levels of polymorphism [11, 61, 62]. Thus, PrP ${ }^{\mathrm{WT}}$ IBs constitute a bacterial reservoir of different PrP amyloid structures that coexist with more disordered aggregates all formed by the same sequence, exemplifying thus conformational diversity. The striking different morphology of $\mathrm{PrP}^{90-231} \mathrm{IBs}$ and $\mathrm{PrP}^{\mathrm{WT}}$ strongly suggests that the $\mathrm{N}$-terminal $\operatorname{PrP}$ is a major contributor to the formation of the detected intracellular ordered amyloid-like assemblies.

\section{Amyloid seeding capacity of PrPWT IBs}

The kinetics of amyloid fibril formation usually follows a sigmoidal curve that reflects a nucleation-dependent growth mechanism [63]. As expected, the in vitro conversion of purified $\mathrm{PrP}^{\mathrm{WT}}$ into fibrils follows this kinetic scheme (Fig. 8), with a lag phase of $\sim 7 \mathrm{~h}$, which corresponds to the formation of the initial nuclei and that is followed by polymerization or fibril growth, as confirmed by TEM imaging of the solution during the aggregation reaction (Fig. 8). Seeded protein aggregation is a well-established mechanism for in vivo amyloid fibril formation and underlies prion propagation [64, 65]. Accordingly, in the presence of $2 \%$ preformed fibrils, the lag phase of the reaction is shortened to $\sim 3.5 \mathrm{~h}$. To test if the detected amyloid-like structures in $\mathrm{PrP}^{\mathrm{WT}}$ IBs were able to template the conversion of its respective soluble species into amyloid fibrils, we performed the aggregation reaction in the presence of limited amounts 


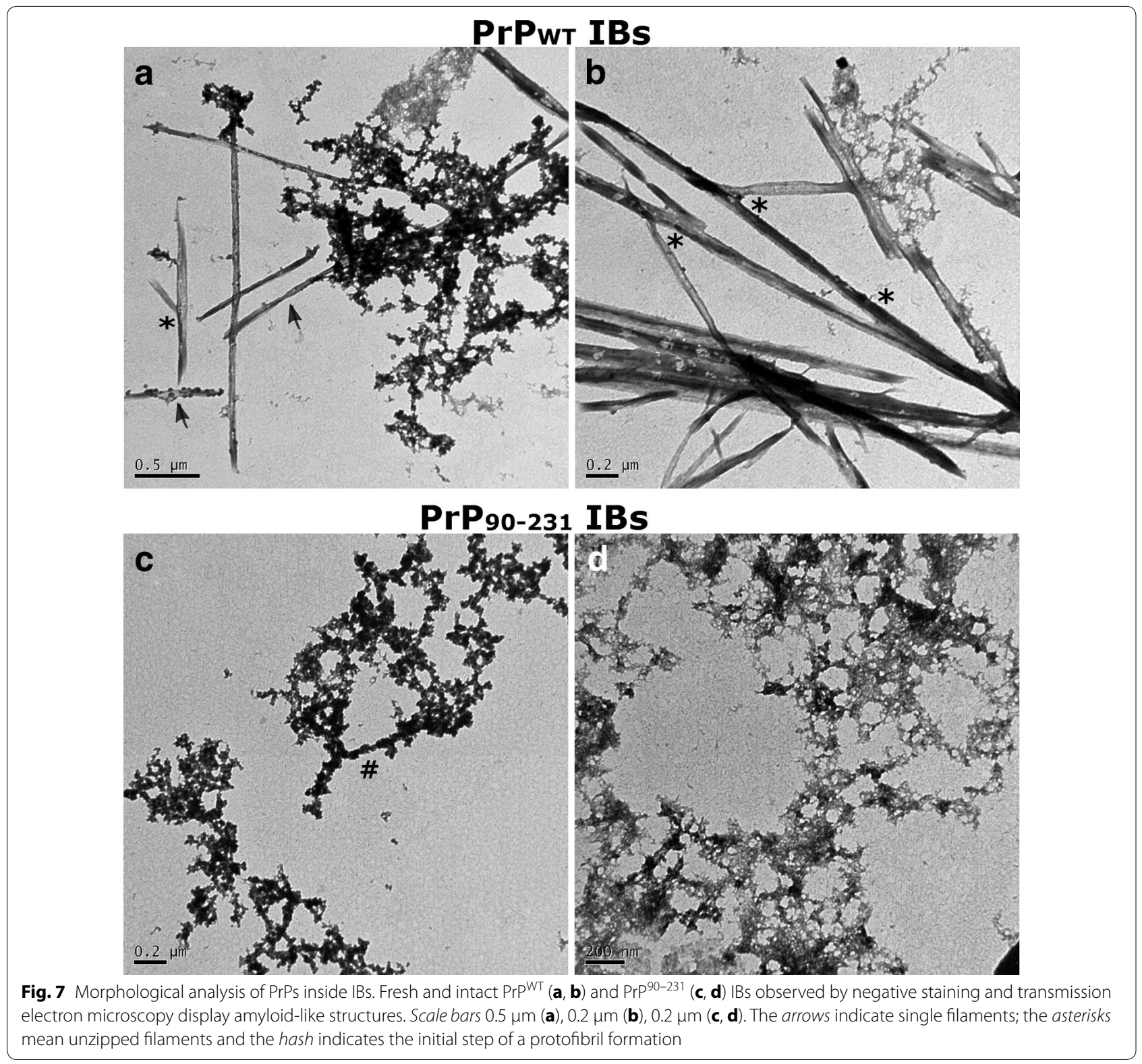

of preformed purified $\mathrm{PrP}^{\mathrm{WT}}$ IBs (Fig. 10). Interestingly enough, the effect exerted by IBs on fibril formation kinetics is similar to that promoted by the corresponding $\operatorname{PrP}^{\mathrm{WT}}$ amyloid fibrils seeds, reducing the lag phase of the reaction to $\sim 2 \mathrm{~h}$. However, in $\operatorname{PrP}^{\mathrm{WT}}$ IBs seeded reactions large aggregates that cannot be maintained in solution appear to accumulate after $12 \mathrm{~h}(720 \mathrm{~min})$ of polymerization (Fig. 10). In contrast to amorphous aggregation, amyloid formation is a specific process that can only be seeded by sequentially and structurally homologous fibrils [66]. To evaluate if such selectivity also applies in the case of PrP IBs, we performed crossseeding experiments, seeding the aggregation reaction of initially soluble $\mathrm{PrP}^{\mathrm{WT}}$ with preformed and purified PrP ${ }^{90-231}$ IBs. Importantly, the presence of $\operatorname{PrP}^{90-231}$ IBs does not have any noticeable impact on the nucleation reaction, the overall kinetics resembling those of a nonseeded reaction (Fig. 10), thus confirming that a specific molecular recognition between soluble and fibrillar states is a requirement for seeding and that in the case of $\operatorname{PrP}^{\mathrm{WT}}$ the N-terminal tail might play a crucial role in this process. Accordingly, it has been previously observed by high-pressure FTIR that the N-terminal domain modulates PrP misfolding and aggregation [67].

We analysed the morphology of the aggregates present in the final reaction of seeded and unseeded kinetics by 

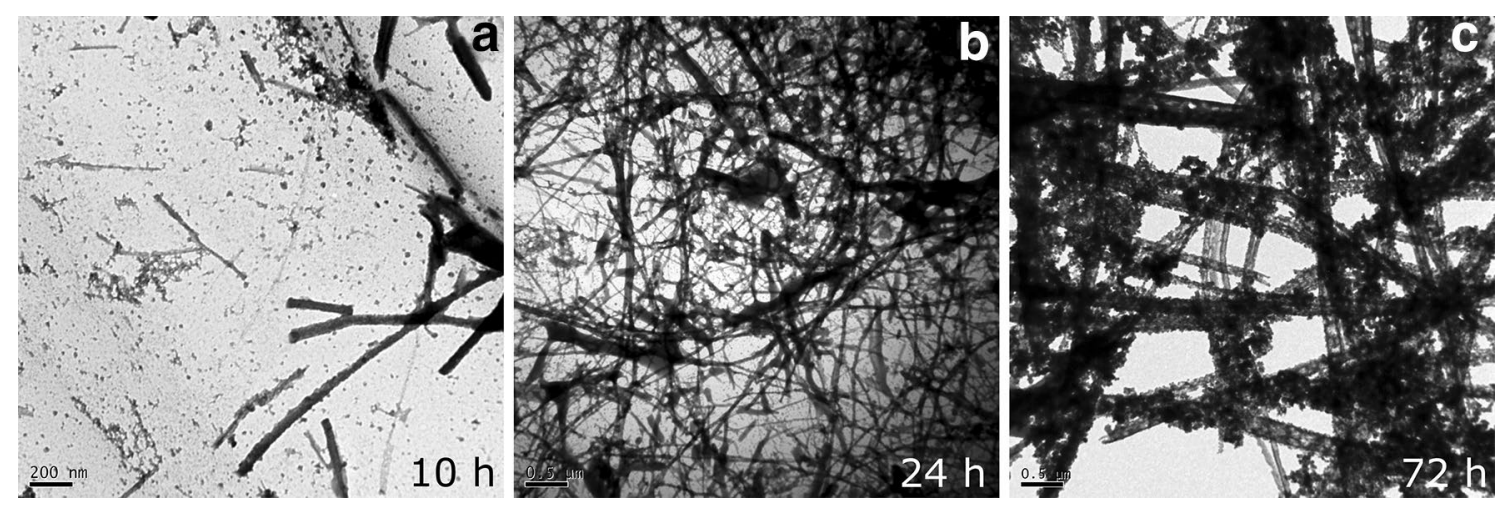

Fig. 8 Evolution of PrPWT aggregates morphology during in vitro aggregation. After purification and refolding PrPWT was converted into amyloid fibrils as described in "Methods". The aggregates morphology was assessed at different times by negative staining and transmission electron microscopy. Scale bars $0.2 \mu \mathrm{m}(10 \mathrm{~h}), 0.5 \mu \mathrm{m}(24 \mathrm{~h})$, and $0.5 \mu \mathrm{m}(72 \mathrm{~h})$

TEM. In agreement with spectroscopic data, the presence of $\operatorname{PrP}{ }^{\mathrm{WT}}$ IBs and fibrils at the beginning of the reaction resulted in an increased number of amyloid fibrils in respect to non-seeded reactions or reactions seeded with PrP ${ }^{90-231}$ IBs. However, the acceleration of the fibrillation promoted by $\operatorname{PrP}^{\mathrm{WT}}$ fibrils and especially by $\operatorname{Pr} \mathrm{P}^{\mathrm{WT}}$ IBs results in the formation of apparently amorphous material tightly associated to the newly formed amyloid fibrils (Fig. 9). Interestingly, we could see after seeding PrP amyloid formation with $\operatorname{PrP}^{\mathrm{WT}}$ IBs the presence of twisted fibrils (Fig. 9). Several early prion studies reported that filamentous structures were found in scrapie-infected rodent brain $[68,69]$. In 1981, one report has called attention to helical fibrils formed by the twisting of two or four filamentous structures; they were found in preparations from brains of scrapie-infected rodents [70]. The ultrastructural morphology of these fibrils was reported to be different from that of many amyloids [71]. Nowadays, there are many reports providing information about the PrP twisted fibrillar structures [60].

Using small amounts of the $\operatorname{PrP}^{\mathrm{WT}}$ IBs seeded solution for re-seeding $\mathrm{PrP}^{\mathrm{WT}}$ soluble protein results in formation of visible fibrillar material that, when analysed by TEM, displays typical amyloid morphology coexisting with more amorphous material, confirming thus the striking ability of $\mathrm{PrP}^{\mathrm{WT}}$ IBs to effectively propagate soluble protein conformational conversion into amyloid structures (Additional file 2).

\section{PrPs IBs display a proteinase $\mathrm{K}$ resistant core}

Proteinase $\mathrm{K}(\mathrm{PK})$ is a protease normally used to map the protected core of amyloid fibrils. Despite its high activity for cleaving peptide bonds, PK cannot attack the highly packed backbones in an amyloid $\beta$-sheet structure. In contrast to soluble forms of PrPs, which are PK-sensitive, aggregated forms of PrP are known to have a PK-resistance profile that can be dependent on the in vitro aggregation conditions or even on the different in vivo sources from where they were extracted (such as diseased brains) [49, 72-75]. To verify the PK-resistance of the two different PrP aggregated deposits formed inside the cell, we evaluated the PK digestion of PrP IBs by tricine SDSPAGE (Fig. 11). There were differences in the PK-digestion pattern between the two PrP IBs. Upon incubation of $\mathrm{PrP}^{\mathrm{WT}}$ IBs with $\mathrm{PK}$, the resistant fibrillar core is visualized as a major band with $16 \mathrm{kDa}$, which corresponds to the PrP C-terminal domain as evidenced by western blot analyses with the anti-PrP antibody R20 that recognizes a C-terminal epitope in PrP (residues 218-232) [76] (Additional file 3). This fragment possesses the same apparent molecular weight of the C-terminal domain (residues 90-231) (16 kDa), indicating that the N-terminal domain was cleaved and the rest of the protein was in a protected conformation. Most of the resultant fragments of PK-digested PrP ${ }^{\mathrm{WT}}$ IBs, which vary from $\sim 15$ to $6 \mathrm{kDa}$ were labeled by R20, and even after $60 \mathrm{~min}$ of reaction the larger fragment (16 kDa) persists (Fig. 11a). Indeed, the PK-resistant core of the pathogenic $\mathrm{PrP}^{\mathrm{Sc}}$ corresponds also to the PrP C-terminal domain [14]. The PK resistance of $\operatorname{PrP}^{\mathrm{WT} T}$ IBs is comparable with the PK-resistant form of $\mathrm{PrP}^{\mathrm{Sc}}$. In $\mathrm{PrP}$ amyloid IBs we studied here, the $16 \mathrm{kDa}$ band resisted PK treatment under conditions that are commonly used for PK reactions with the scrapie brain homogenates (incubation for $1 \mathrm{~h}$ at neutral $\mathrm{pH})[77,78]$. In addition, this same resistant fragment $(16 \mathrm{kDa})$ is also observed upon PK-digestion of the in vitro-formed PrP amyloid fibrils [79]. In contrast, PKdigestion of $\operatorname{PrP}^{90-231}$ IBs showed a different profile; after $30 \mathrm{~min}$ of PK-treatment the apparent $16 \mathrm{kDa}$ fragment was completely degraded, and the remaining resistant 


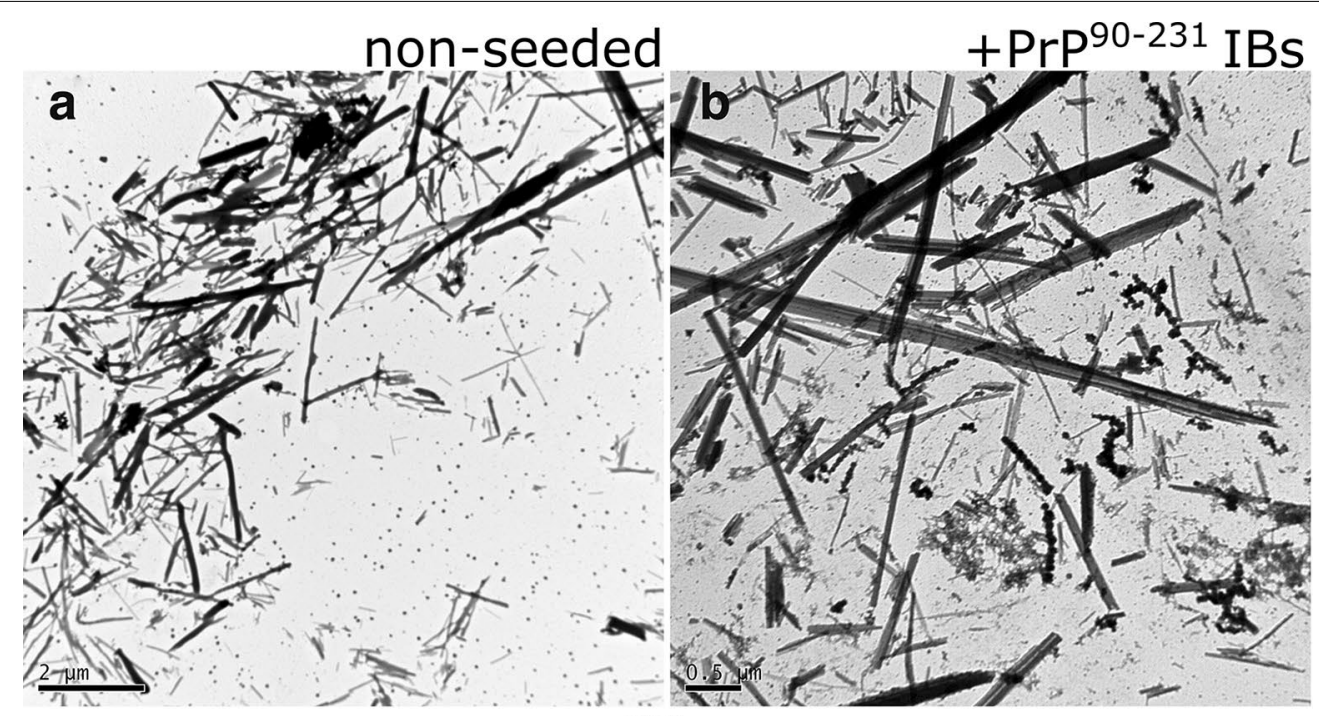

+ PrPWT fibrils
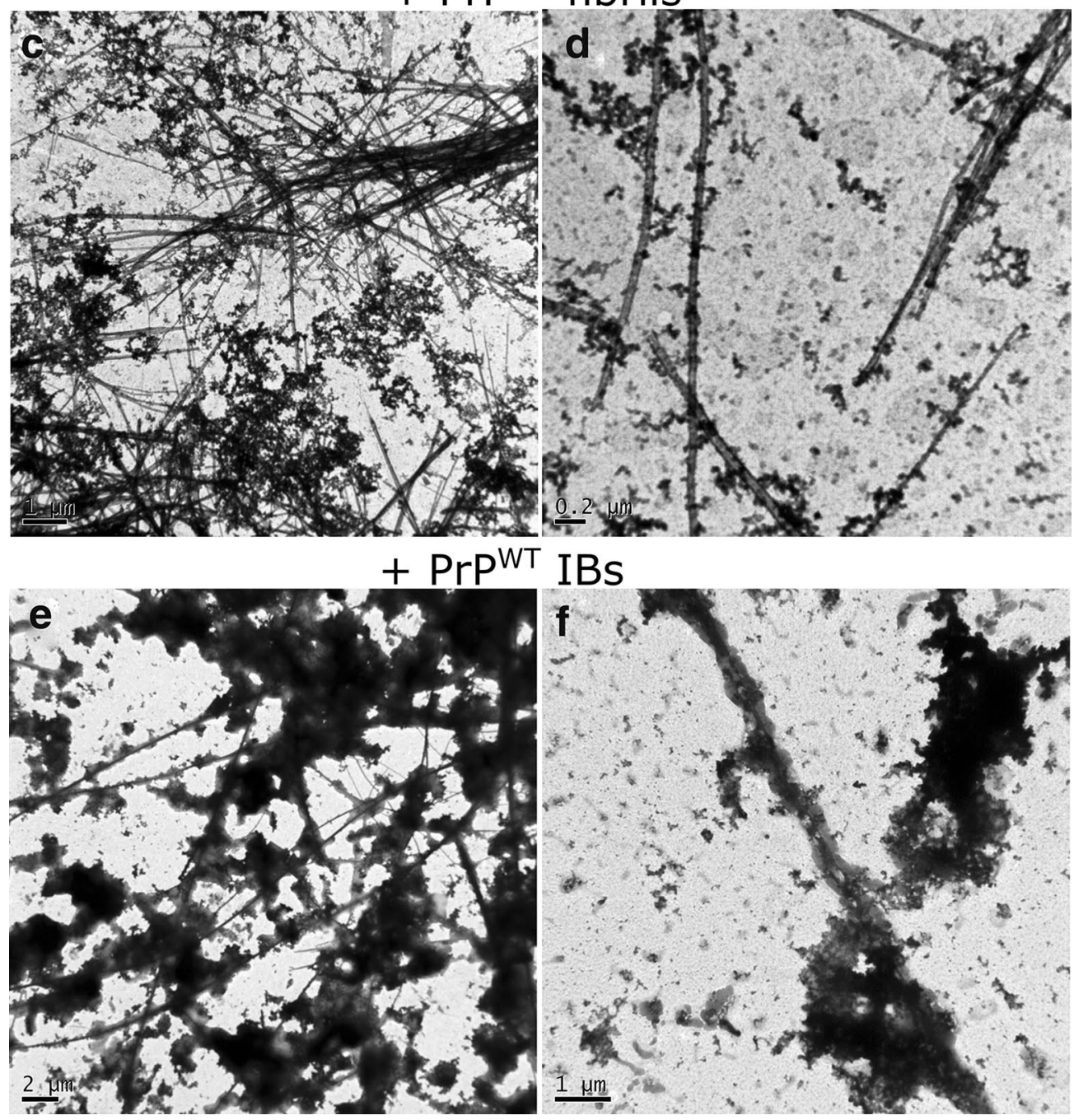

Fig. 9 Morphology of PrP ${ }^{W T}$ aggregates at the end of the aggregation kinetics. Aggregates were collected at the end ( 19 h) of non-seeded (a), seeded $(\mathbf{c}-\mathbf{f})$ and cross-seeded $(\mathbf{b})$ reactions (Fig. 10) and they were monitored by negative staining and transmission electron microscopy. Scale bars $2 \mu \mathrm{m}(\mathbf{a}) ; 0.5 \mu \mathrm{m}(\mathbf{b}) ; 1.0 \mu \mathrm{m}(\mathbf{c}) ; 0.2 \mu \mathrm{m}(\mathbf{d}) ; 2 \mu \mathrm{m}(\mathbf{e}) ; 1 \mu \mathrm{m}(\mathbf{f})$ 


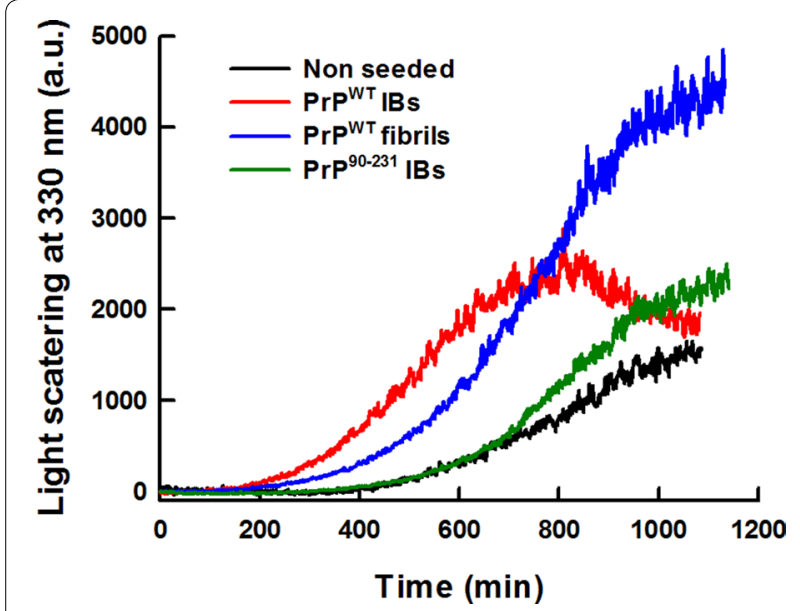

Fig. 10 Aggregation kinetics of PrPWT . The aggregation reactions of $0.5 \mathrm{mg} / \mathrm{mL}$ of purified and refolded $\mathrm{rPr} \mathrm{P}^{\mathrm{WT}}$ were carried out under constant agitation at $600 \mathrm{RPM}$ and $37^{\circ} \mathrm{C}$. In vitro preformed fibrils $(2 \%)$ or PrPs IBs (final $O_{350}=0.1$ ) were used for seeding and crossseeding assays. PrP fibrilization (black line) as a function of time, exhibits a typical nucleation-elongation profile. The lag phase is reduced in the presence of pre-aggregated homologous protein, either PrPWT fibrils (blue line) or PrPWT IBs (red line). Cross-seeding with PrP ${ }^{90-231}$ IBs (green line) did not affect the fibrilization extent and kinetics

fragments have lower molecular mass (Fig. 11b). These PrP IBs do not possess the same conformation and, thus, as expected, differ in their biochemical and biophysical properties. Recently, it was shown that full-length recombinant PrP (23-231) can aggregate into a $\beta$-sheet-rich oligomeric species ( 12 PrP molecules), and that the protein N-terminal region (23-90) was necessary for the formation of this oligomer [80]. At the same condition, PrP lacking part of the N-terminal region (PrP91-231) aggregated into heterogeneous species [80]. It is increasingly recognized the essential role of the $\mathrm{N}$-terminal domain in directing $\operatorname{PrP}$ intermolecular association and in promoting the stability and proper folding of the C-terminal domain [80-82]. Taken together, this result is in good agreement with the lower stability we have shown to extracted $\mathrm{PrP}^{90-231}$ IBs relative to PrP ${ }^{\mathrm{WT}}$ IBs (Fig. 4).

To confirm the conformational diversity exhibited by PrP ${ }^{90-231}$ and $\mathrm{PrP}^{\mathrm{WT}}$ we explored whether their differently protected amyloid cores display different cytotoxic properties. To this aim PrP IBs where digested with PK for $60 \mathrm{~min}$, the protease was inactivated and the digested aggregates were administered to neuroblastoma SH-SY5Y cells. The combination of SYBR green and propidium iodide (PI) staining allows assessing the cell viability by confocal fluorescence microscopy, as viable cells are permeable to SYBR green and PI only enters cells with permeabilized membranes corresponding to dead cells. The impact of aggregates in cell morphology was also monitored (Fig. 12). Cells treated with inactivated PK were used as negative controls. Cells treated with the PK-resistant PrP $\mathrm{P}^{90-231}$ core exhibited normal morphology and were not stained with PI, indicating that it does not exert significant toxicity. In contrast, the PK-resistant PrP ${ }^{\mathrm{WT}}$ core was neurotoxic, since its presence resulted in cell death (cells were stained with PI) and in abnormal cell morphology. Although the prion infectious region is attributed to the resistant 90-231 core (PrP27-30 in vivo), we did not see neurotoxic activity for $\mathrm{PK}$-digested $\operatorname{PrP}^{90-231} \mathrm{IBs}$, only for digested PrP ${ }^{\mathrm{WT}}$ IBs. We showed here that the protease-resistant region of the $\mathrm{PrP}^{\mathrm{WT}} \mathrm{IBs}$, after $60 \mathrm{~min}$ of reaction, belongs to the $\mathrm{C}$-terminal domain in contrast to $\mathrm{PrP}^{90-231}$ IBs digestion, which renders smaller fragments that do not bind to PrP antibody (R20) (Additional File 3). One might speculate that the largest fragment of the $\mathrm{C}$-terminal resistant to $\mathrm{PK}$-digestion (the $16 \mathrm{kDa}$ fragment) is necessary to retain cytotoxicity; this fragment might have its intact disulphide bridge which is well known to be necessary to cause prion diseases [83]. Further experiments will be required to address which are the residues involved in the toxic conformations we have seen for these PrP ${ }^{\mathrm{WT}}$ IBs PKresistant core. Therefore, they are not the same species, and thus, are expected to result in different cytotoxic effects. Probably, the low molecular weight fragments derived from $\mathrm{PrP}^{90-231}$ IBs are not properly folded into a toxic conformation. Moreover, the amount of PK-resistant fragments for both PrP constructs differs, as the sensitivity to $\mathrm{PK}$ is depends on the aggregated structure.

\section{Conclusions}

Prions are misfolded, self-propagating and infectious proteins. The bacterial inclusion bodies formed by fungal prions, such as HET-s PFD, Ure2p and Sup35-NM have been shown to display an amyloid fold and to be infective. This ability to embrace potentially harmful misfolded polypeptides into insoluble deposits seems to be a strategy mechanism perpetuated along the evolution from prokaryotic bacteria to highly complex eukaryotic organisms. We showed here for the first time that the IBs formed by mammalian prion proteins are also enriched in seeding competent amyloid-like structures, supporting the formation of prion-like conformations inside bacteria. Moreover, these aggregates display conformational diversity, thus becoming an interesting and simple model to study how this property can be modulated in vivo by the quality control machinery. Since PrP accumulates in IBs at high levels and these biological particles are easily purified, it is suggested that they might become a convenient source to obtain prion particles. It is clear that the bacterial cytosol where these aggregates are formed 


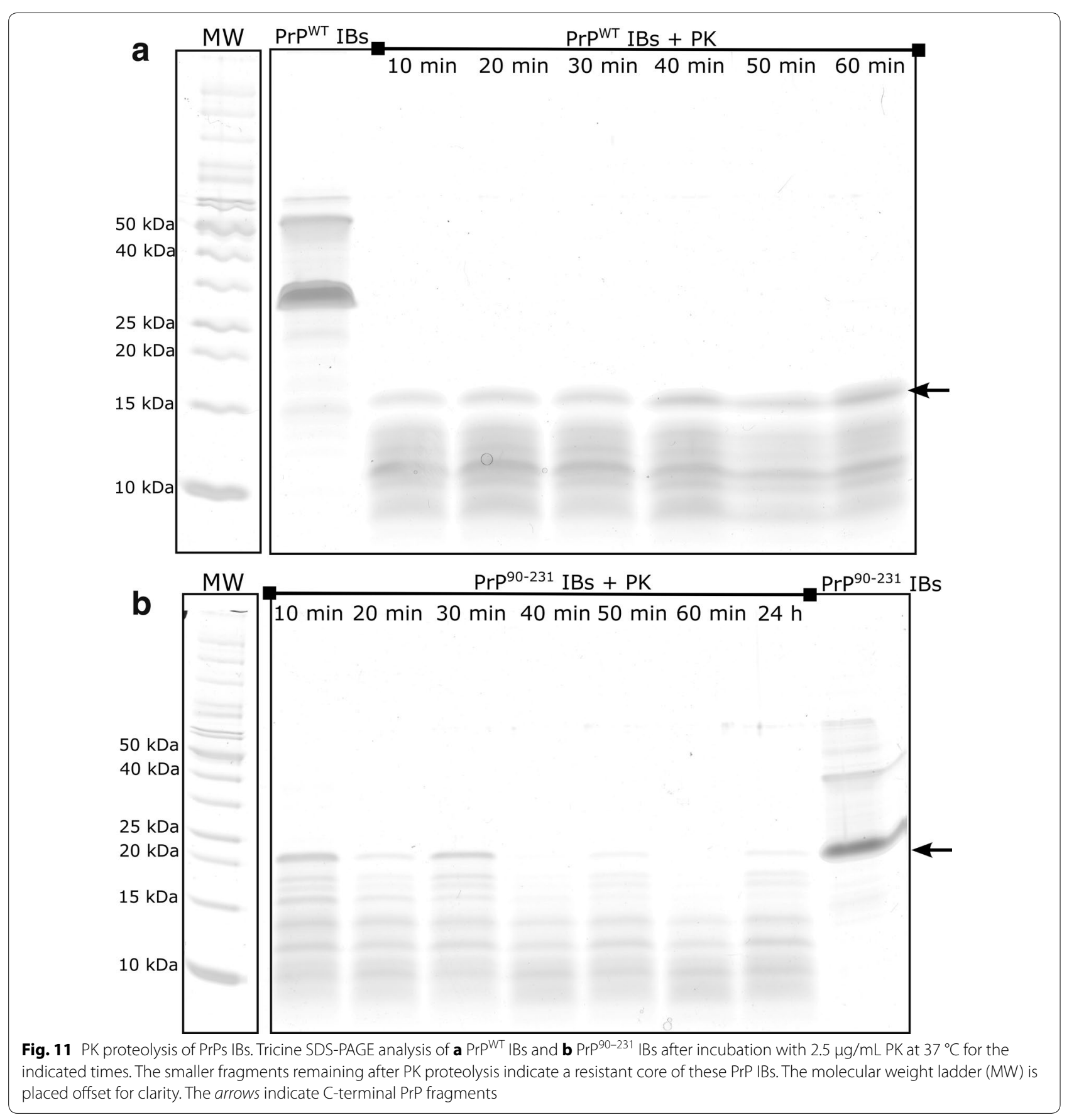

differs from that of eukaryotic cells; however, the potentiality of these inside-the-cell formed amyloid particles to adopt infective conformations is, in our opinion, much higher than the one of the aggregates formed by the purified recombinant protein in vitro after complete denaturation and refolding procedures. In addition, as already shown for other amyloids [15], PrP-producing bacterial cells can potentially be used for the easy and cheap screening of anti-aggregation compounds able to prevent intracellular PrP amyloid-like aggregation, being thus useful in the early stages of discovery of anti-prionic drugs.

\section{Methods}

\section{Prion proteins expression and purification}

E. coli C43 (DE3) cells were transformed with plasmids (pET-28 b) encoding the murine wild-type prion protein $\left(\mathrm{PrP}^{\mathrm{WT}}\right)$ encompassing residues $23-231$ and the murine 


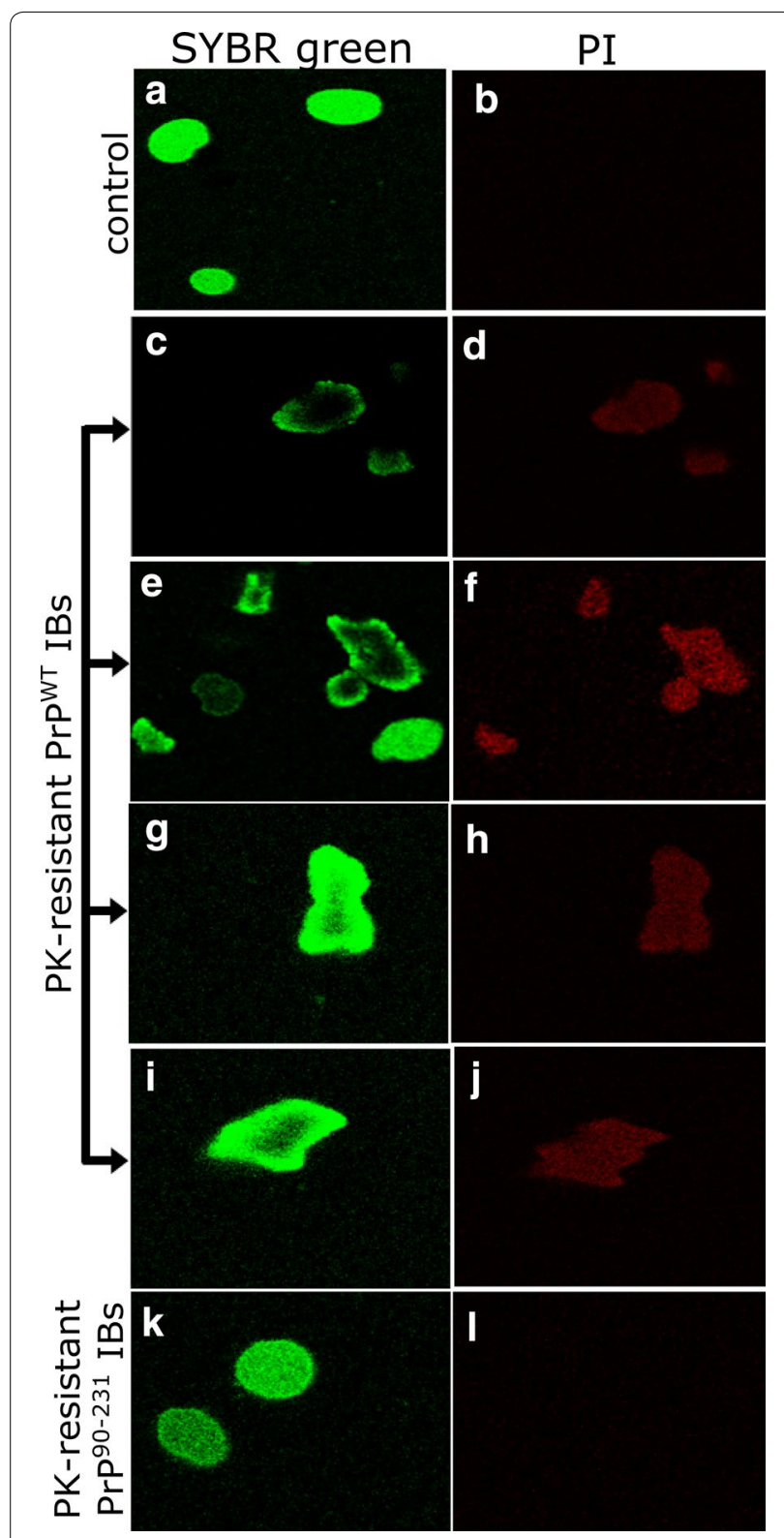

Fig. 12 Cytotoxicity of the PK-resistant core of PrP IBs visualized by confocal microscopy. Confocal fluorescence microscopy images of SH-SY5Y cells stained with SYBR green or propidium iodide (PI). Cells were treated with PK-derived fragments of PrPWT IBs (panels $\mathbf{C}-\mathbf{j}$ ), or $\operatorname{PrP}{ }^{90-231}$ IBs $(\mathbf{k}, \mathbf{I})$. All samples were incubated with PK for $1 \mathrm{~h}$ at $37^{\circ} \mathrm{C}$ and PK was inactivated before applying to cells. Inactivated PK in PBS was used as control $(\mathbf{a}, \mathbf{b})$. Representative images of two independent experiments done in duplicate are shown. Further details are described in the "Methods"

PrP C-terminal domain residues 90-231 ( $\left.\operatorname{PrP}^{90-231}\right)$, both containing a histidine-tag. Cells were grown aerobically in liquid Luria-Bertani (LB) medium containing appropriate antibiotics in a rotary shaker at $37{ }^{\circ} \mathrm{C}$ and 250 RPM. Overnight cultures were diluted 100-fold in LB and allowed to grow to an $\mathrm{OD}_{600}=0.7$. At $\mathrm{OD}_{600}=0.7$, expression was induced with $1 \mathrm{mM}$ isopropyl-1-thio- $\beta$ D-galactopyranoside (IPTG). Cells were harvested after overnight induction (18-20 h), centrifuged, resuspended in $60 \mathrm{~mL}$ of buffer $\mathrm{U}$ ( $8 \mathrm{M}$ urea, $10 \mathrm{mM}$ Tris- $\mathrm{HCl}, 100 \mathrm{mM}$ $\mathrm{NaH}_{2} \mathrm{PO}_{4}, 10 \mathrm{mM}$ reduced glutathione, $\mathrm{pH}$ 8.0). After sonication and centrifugation, the soluble protein fraction was added to $5 \mathrm{~mL}$ of HisTrap FF prepacked column (GE Healthcare) and washed with $30 \mathrm{~mL}$ of buffer U. On-column oxidative refolding was performed by applying for $2 \mathrm{~h}$ a $160 \mathrm{~mL}$-gradient of buffer $\mathrm{U}$ to buffer B (10 mM Tris$\mathrm{HCl}, 100 \mathrm{mM} \mathrm{NaH} \mathrm{PO}_{4}, \mathrm{pH}$ 8.0). Then, the column was washed with $50 \mathrm{~mL}$ buffer B. Unspecific bound proteins were removed from the column with $50 \mathrm{~mL}$ of $50 \mathrm{mM}$ imidazole in buffer $\mathrm{B}$. The recombinant proteins $\mathrm{PrP}^{\mathrm{WT}}$ and $\mathrm{PrP}^{90-231}$ were eluted with buffer E (10 mM Tris, $100 \mathrm{mM}$ $\mathrm{NaH}_{2} \mathrm{PO}_{4}, 750 \mathrm{mM}$ imidazole, pH 5.8). Histidine tail-fused PrP was dialyzed against milliQ water at least two times. The histidine tail was removed from the prion protein using thrombin (1:1000). The cleavage reaction was carried out at room temperature for $2 \mathrm{~h}$. After thrombin cleavage, the sample was repurified in the HisTrap column. Finally, the protein solution was dialyzed against milliQ water two times to remove any remaining salt. $15 \%$ SDS-PAGE analysis revealed more than $95 \%$ of purity.

\section{PrPWT and PrP ${ }^{90-231}$ IBs extraction}

IBs were purified from IPTG-induced cells harbouring the $\mathrm{pET}-28(\mathrm{~b}) / \mathrm{PrP}^{\mathrm{WT}}$ plasmid, the $\mathrm{pET}-28(\mathrm{~b}) / \mathrm{PrP}^{90-231}$ plasmid and vector alone by detergent-based procedures. IBs were purified from induced cell extracts by detergentbased procedures as previously described [17]. Briefly, cells in a $10 \mathrm{~mL}$ culture were harvested by centrifugation at $12,000 \mathrm{~g}\left(\right.$ at $4{ }^{\circ} \mathrm{C}$ ) for $15 \mathrm{~min}$ and resuspended in $200 \mu \mathrm{L}$ of lysis buffer (50 mM Tris- $\mathrm{HCl}$ pH 8.0, $1 \mathrm{mM}$ EDTA, $100 \mathrm{mM} \mathrm{NaCl}$ ), plus $30 \mu \mathrm{L}$ of $100 \mathrm{mM}$ protease inhibitor PMSF and $6 \mu \mathrm{L}$ of a $10 \mathrm{mg} / \mathrm{mL}$ lysozyme solution. After $30 \mathrm{~min}$ of incubation at $37{ }^{\circ} \mathrm{C}$ under gentle agitation, Nonidet-P40 was added at $1 \%(\mathrm{v} / \mathrm{v})$ and the mixture was incubated at $4{ }^{\circ} \mathrm{C}$ for $30 \mathrm{~min}$. Then, DNase I and RNase were added to a final concentration of $25 \mu \mathrm{g} / \mathrm{mL}$ and $3 \mu \mathrm{L}$ of $1 \mathrm{M} \mathrm{MgSO}_{4}$ was added. The resulting mixture was further incubated at $37{ }^{\circ} \mathrm{C}$ for $30 \mathrm{~min}$. Protein aggregates were separated by centrifugation at $12,000 \mathrm{~g}$ at $4{ }^{\circ} \mathrm{C}$ for $15 \mathrm{~min}$. Finally, IBs were washed once with the same buffer containing $0.5 \%$ Triton X-100 and once with phosphate buffered saline (PBS). After a final centrifugation at $12,000 \mathrm{~g}$ for $15 \mathrm{~min}$, pellets were stored at $-20^{\circ} \mathrm{C}$ until analysis. The frozen pellets were reconstituted in PBS. SDS-PAGE analysis revealed that in all cases the murine prion proteins were the major polypeptidic components of the aggregates. Prion proteins concentration in IBs was estimated using image densitometry software 
Image in the SDS-PAGE gel analysis in comparison with the respective dosed purified protein. We performed the same procedures with cells extracts of bacteria containing an empty plasmid as control IBs.

\section{Secondary structure determination}

Attenuated total reflectance (ATR)-Fourier Transformed Infrared spectroscopy analyses of $\operatorname{PrP}^{\mathrm{WT}}$ and $\operatorname{PrP}^{90-231}$ IBs were performed using a Nicolet 6700 IR spectrometer (Thermo Scientific, USA) equipped with an ATR accessory. Dried samples were applied directly to the ATR crystal to be analysed. Each spectrum consisted of 128 accumulated scans, measured at a spectral resolution of $4 \mathrm{~cm}^{-1}$ within the mid-IR range $\left(4000-675 \mathrm{~cm}^{-1}\right)$. Fourier deconvolution of the FTIR spectra was performed with a resolution enhancement factor of 1.6 and a bandwidth of $21 \mathrm{~cm}^{-1}$. Peak position and curve fitting were determined with $\mathrm{OMNIC}^{\mathrm{TM}}$ software v. 8.0 (Thermo Scientific WI, USA) with a mixed GaussianLorenztian function, allowing assignment of different secondary structure components in the amide I range $\left(1700-1600 \mathrm{~cm}^{-1}\right)[47,48,67]$.

\section{Congo red binding}

To get insights into the amyloid nature of the $\mathrm{PrP}^{\mathrm{WT}}$ and $\mathrm{PrP}^{90-231}$ IBs, CR binding assays were performed. The interaction of $20 \mu \mathrm{M} \mathrm{CR}$ with the purified IBs (final $\left.\mathrm{OD}_{600}: 0.1\right)$ was tested using a Cary100 UV/Vis spectrophotometer (Varian, Palo Alto, CA, USA). CR binding was quantified by the equation: $\mathrm{CR}$ bound $=\mathrm{Abs}_{540 \mathrm{~nm}} / 25$, $295-\mathrm{ABS}_{477 \mathrm{~nm}} / 46,306$ [84]. The extent of amyloid structure was measured by the increase of $\mathrm{CR}$ bound to $\operatorname{PrP}$ IBs in relation to control IBs [IBs purified from IPTGinduced cells harbouring only the pET-28(b) plasmid].

\section{Thioflavin $\mathrm{T}$ (Th-T) binding assay}

Th-T binding was used to probe amyloid presence in the samples. Incubation of $30 \mu \mathrm{M}$ Th-T with $\mathrm{PrP}^{\mathrm{WT}} \mathrm{IBs}$ and $\operatorname{PrP}^{90-231}$ IBs (final $\mathrm{OD}_{600}$ : 0.1) or the correspondent amyloid fibrils was recorded using a Jasco FP-8200 spectrofluorometer (Jasco Inc, MD, USA) with an excitation wavelength of $445 \mathrm{~nm}$ and emission range from 480 to $580 \mathrm{~nm}$ at $37{ }^{\circ} \mathrm{C}$ in PBS. Five individual scans were averaged for each measurement. The intensity of the spectra at the $482 \mathrm{~nm}$ maximum was recorded as an indication of the extent of amyloid conformation in the aggregates.

\section{Thioflavin-S binding in living cells}

Detection of thioflavin-S (Th-S) binding was performed in living cells expressing $\operatorname{PrP}^{\mathrm{WT}}$, or $\operatorname{PrP}^{90-231}$ and control non-induced cells. Bacterial cells were washed with PBS buffer and diluted at an $\mathrm{OD}_{600}$ of 0.1. Th-S was added at $125 \mu \mathrm{M}$ final concentration; cells were then incubated for $1 \mathrm{~h}$ and washed twice with PBS. Cells were placed on top of a microscope slide and covered with a cover slip. Photographs were acquired at 40-fold magnification under UV light in a Leica fluorescence microscope (Leica DMRB, Heidelberg, Germany).

\section{Chemical denaturation}

For stability assays, purified $\operatorname{PrP}{ }^{\mathrm{WT}}$ and $\operatorname{PrP}^{90-231}$ IBs were prepared at final $\mathrm{OD}_{350}=1$ in PBS containing selected concentrations of urea ranging from 0 to $8 \mathrm{M}$. The reactions were allowed to reach equilibrium by incubating them for $12 \mathrm{~h}$ at room temperature. The fraction of soluble protein $\left(f_{S}\right)$ was calculated from the fitted values using equation: $f_{S}=1-\left(\left(y_{S}-y\right) /\left(y_{S}-y_{A}\right)\right)$, where $y_{S}$ and $y_{A}$ are the absorbance at $350 \mathrm{~nm}$ of the soluble and aggregated protein, respectively, and $y$ is the absorbance of the protein solution as a function of the denaturant concentration. The value $m_{1 / 2}$ was calculated as the denaturant concentration at which $\mathrm{f}_{\mathrm{S}}=1 / 2 . \mathrm{OD}_{350}$ changes were monitored with a Cary 400 Varian spectrophotometer.

\section{Transmission electron microscopy (TEM)}

Each sample $(20 \mu \mathrm{L})$ was applied to a carbon coated copper grid, and after 5 min the grid was washed with MilliQ water. Samples were stained with $2 \%$ (w/v) uranyl acetate for $1 \mathrm{~min}$ and then washed again. Images were collected on a Jeol 1200 microscope (Boston, MA, USA) operating at $80 \mathrm{kV}$.

\section{In vitro conversion of PrP into amyloid fibrils}

To target amyloid fibril formation, $\operatorname{PrP}$ solutions were prepared immediately before use by resuspending lyophilized purified $\operatorname{PrP}^{\mathrm{WT}}$ powder in $4 \mathrm{M} \mathrm{GdnHCl}, 0.02 \mathrm{M}$ thiourea, and 0.1 M MES, $\mathrm{pH}$ 6.0, in a protocol adapted from previous studies [59]. Samples were centrifuged at $12,000 \mathrm{~g}$ for $5 \mathrm{~min}$ and the protein concentration was determined by its extinction coefficient at $280 \mathrm{~nm}$ $\left(63,495 \mathrm{M}^{-1} \mathrm{~cm}^{-1}\right)$, calculated from the PrP ${ }^{\mathrm{WT}}$ primary sequence in http://web.expasy.org/protparam/. The fibrillation reactions of $0.5 \mathrm{mg} / \mathrm{mL} \operatorname{PrP}$ were carried out in 1.5-ml conical low-binding plastic tubes up to a total reaction volume of $0.6 \mathrm{ml}$ at $37^{\circ} \mathrm{C}$ with continuous shaking at $600 \mathrm{rpm}$ for at least 3 days using an Eppendorf Thermomixer Comfort (Eppendorf, USA). Aliquots from each sample were taken over time.

\section{Seeding assays}

PrP aggregation departing from monomeric recombinant PrP was monitored by measuring the transition from non-aggregated to aggregated state by following light 
scattering at $350 \mathrm{~nm}$ in a Jasco FP-8200 spectrofluorometer (Jasco Inc, MD, USA). The polymerization reactions showed typical nucleation-elongation kinetics of amyloid formation. The reactions were carried out with $0.5 \mathrm{mg} /$ $\mathrm{mL}$ of soluble purified $\operatorname{PrP}^{\mathrm{WT}}$ in $4 \mathrm{M} \mathrm{GdnHCl}, 0.02 \mathrm{M}$ thiourea, and 0.1 M MES pH 6.0 using $1 \mathrm{~cm}$-path length quartz cuvette in a total reaction volume of $1 \mathrm{~mL}$ at $37^{\circ} \mathrm{C}$ with continuous shaking at $600 \mathrm{rpm}$ using micro-stir bars. In the seeding assays, a solution of $\operatorname{Pr} \mathrm{P}^{\mathrm{WT}}$ IBs resuspended in PBS with $\mathrm{OD}_{350}$ of 10.0 were sonicated for $10 \mathrm{~min}$, and then diluted 100 -fold (final $\mathrm{OD}_{350}=0.1$ ) at the beginning of the reaction. The seeding ability of $2 \%$ preformed fibrils (after $10 \mathrm{~min}$ of sonication) was also evaluated. Cross-seeding assays were performed in the same manner by adding a sonicated solution of $\operatorname{Pr} \mathrm{P}^{90-231}$ IBs (final $\mathrm{OD}_{350}=0.1$ ) to initially soluble $\operatorname{Pr} \mathrm{P}^{\mathrm{WT}}$.

\section{Confocal microscopy and image processing}

Confocal images of human neuroblastoma (SH-SY5Y) cell cultures were captured in complete medium at $37^{\circ} \mathrm{C}$, using a laser scanning confocal microscope (Leica TCS SP2 AOBS equipped with a HCX PL APO $63 \times 1.4$ oil, immersion objective, Germany). Briefly, SH-SY5Y cells were seeded in $35 \mathrm{~cm}^{2}$ plates (Mat Tek) with approximately $30 \%$ of confluence in complete medium and incubated for $72 \mathrm{~h}$ in the presence of sterile PBS buffer + PK (positive control) and the PK-resistant core of the PrPs IBs. Proteinase $\mathrm{K}$ was inactivated by boiling all solutions before applying them to cultured cells. Cells were incubated with $0.5 \mu \mathrm{g} / \mathrm{mL}$ SYTO green and $10 \mu \mathrm{g} / \mathrm{mL}$ propidium iodide (PI) (Molecular Probes) for $15 \mathrm{~min}$ at $37^{\circ} \mathrm{C}$ and washed twice with PBS buffer. Cell morphology was analysed by confocal fluorescence microscopy using an orange diode (588-715 $\mathrm{nm}$ emission collected) and a UV laser (excited at $350 \mathrm{~nm}$ and collected at $405 \mathrm{~nm}$ ). Two independent experiments, both in duplicate were done and the entire field of each plate was observed at the microscope.

\section{Proteinase $\mathrm{K}(\mathrm{PK})$ resistance assay}

The PK concentration in this assay was optimized in preliminary experiments (not shown). PrP $\mathrm{P}^{\mathrm{WT}} \mathrm{IBs}$ and $\mathrm{PrP}^{90-231} \mathrm{IBs}$ at final $\mathrm{OD}_{350}$ of 0.5 were incubated with PK (Sigma-Aldrich, USA) at final concentration of $2.5 \mu \mathrm{g} /$ $\mathrm{mL}$ in PBS for $1 \mathrm{~h}$ at $37^{\circ} \mathrm{C}$. Aliquots of PK digestion were taken at every $10 \mathrm{~min}$ and the reaction quenched by the addition of the same amount of 4 times concentrated denaturing sample buffer. Samples were heated at $95{ }^{\circ} \mathrm{C}$ for $5 \mathrm{~min}$ and analysed by Tris-Glycine SDS-PAGE. The assay with soluble purified recombinant $\operatorname{PrP}$ was performed in the same manner [85].

\section{Additional files}

Additional file 1. In the Supplemental Material Section the Amide I region of the ATRFTIR spectrum of purified native recombinant Pr P23-231 is shown, along with the corresponding spectral bands assigned to different secondary structure components.

Additional file 2. In the Supplemental Material Section results from visual and TEM observation of fibrils formed after a second consecutive round of PrPWT aggregation using PrP ${ }^{W T} I B s$ as seeds are presented.

Additional file 3. In the Supplemental Material Section results from western blot analyses of PrPWT IBs and PrP ${ }^{90-231}$ IBs after PK-digestion are presented.

\section{Authors' contributions}

BM carried out most of the experiments and drafted the manuscript. RS and SN participated in the experimental work. SV and YC supervised the project and revised the manuscript. All authors read and approved the final manuscript.

\section{Author details}

${ }^{1}$ Faculdade de Farmácia, Centro de Ciências da Saúde, Universidade Federal do Rio de Janeiro, Av. Carlos Chagas Filho 373, Bloco B, Subsolo, Sala 17, Rio de Janeiro, RJ 21941-902, Brazil. ${ }^{2}$ Institut de Biotecnologia i de Biomedicina, Universitat Autònoma de Barcelona, 08193 Bellaterra, Spain. ${ }^{3}$ CAPES Foundation, Ministry of Education of Brazil, Brasilia, DF 70040-020, Brazil. ${ }^{4}$ Departament de Bioquímica i Biologia Molecular, Facultat de Biociències, Universitat Autònoma de Barcelona, 08193 Bellaterra, Spain.

\section{Acknowledgements}

We thank Pablo Castro for help with microscopy analysis and we also thank Dr. Byron Caughey (RML, NIH) for providing us the rabbit polyclonal anti-PrP antibody R20. This work was supported by Ministry of Education of Brazil [CAPES process number: 99999.002869/2014-04 to the fellow student B.M]; and by Ministerio de Economia y Competividad, Spain [BFU2013-44763P to S.V.]; by ICREA [ICREA Academia 2009 to S.V.] and by FAPERJ, CNPq and INBEB from Brazil to Y.C.

\section{Competing interests}

The authors declare that they have no competing interests.

Received: 6 July 2015 Accepted: 17 October 2015

Published online: 04 November 2015

\section{References}

1. Chiti F, Dobson CM. Protein misfolding, functional amyloid, and human disease. Annu Rev Biochem. 2006;75:333-66.

2. Sipe JD, Cohen AS. Review: history of the amyloid fibril. J Struct Biol. 2000;130:88-98.

3. Prusiner SB. Nobel Prize Lecture: prions. Proc Natl Acad Sci USA. 1998;95(November):13363-83.

4. Riek R, Hornemann S, Wider G, Billeter M, Glockshuber R, Wüthrich K. NMR structure of the mouse prion protein domain $\operatorname{PrP}(121-231)$. Nature. 1996;382:180-2.

5. Zahn R, Liu A, Lührs T, Riek R, von Schroetter C, López Garcia F, Billeter M, Calzolai L, Wider G, Wüthrich K. NMR solution structure of the human prion protein. Proc Natl Acad Sci. 2000;97:145-50.

6. Cohen FE, Prusiner SB. Pathologic conformations of prion proteins. Annu Rev Biochem. 1998;67:793-819.

7. Caughey B, Baron GS, Chesebro B, Jeffrey M. Getting a grip on prions: oligomers, amyloids, and pathological membrane interactions. Annu Rev Biochem. 2009;78:177-204. 
8. Baskakov IV, Legname G, Baldwin MA, Prusiner SB, Cohen FE. Pathway complexity of prion protein assembly into amyloid. J Biol Chem. 2002;277:21140-8.

9. Sabaté R, Castillo V, Espargaró A, Saupe SJ, Ventura S. Energy barriers for HET-s prion forming domain amyloid formation. FEBS J. 2009;276:5053-64.

10. Shorter J, Lindquist S. Prions as adaptive conduits of memory and inheritance. Nat Rev Genet. 2005;6:435-50.

11. Baskakov IV. Switching in amyloid structure within individual fibrils: implication for strain adaptation, species barrier and strain classification. FEBS Lett. 2009;583:2618-22.

12. Poggiolini I, Saverioni D, Parchi P. Prion protein misfolding, strains, and neurotoxicity: an update from studies on mammalian prions. Int J Cell Biol. 2013;2013:910314. doi:10.1155/2013/910314.

13. Telling GC. The mechanism of prion strain propagation. Genome Biol. 2004;5:222.

14. Weissmann C. Birth of a prion: spontaneous generation revisited. Cell. 2005;122:165-8.

15. Sabate R, De Groot NS, Ventura S. Protein folding and aggregation in bacteria. Cell Mol Life Sci. 2010;67:2695-715.

16. De Groot NS, Sabate R, Ventura S. Amyloids in bacterial inclusion bodies. Trends Biochem Sci. 2009;34:408-16.

17. Morell M, Bravo R, Espargaró A, Sisquella X, Avilés FX, FernàndezBusquets $X$, Ventura $S$. Inclusion bodies: Specificity in their aggregation process and amyloid-like structure. Biochim Biophys Acta Mol Cell Res. 2008;1783:1815-25

18. Dasari M, Espargaro A, Sabate R, Lopez Del Amo JM, Fink U, Grelle G, Bieschke J, Ventura S, Reif B. Bacterial inclusion bodies of Alzheimer's Disease $\beta$-amyloid peptides can be employed to study native-Like aggregation intermediate states. Chembiochem. 2011;12:407-23.

19. Fernández-Tresguerres ME, Moreno-Díaz de la Espina S, Gasset-Rosa F, Giraldo R. A DNA-promoted amyloid proteinopathy in Escherichia coli. Mol Microbiol. 2010;77:1456-69.

20. Villar-Pique A, De Groot NS, Sabaté R, Acebrón SP, Celaya G, FernàndezBusquets X, Muga A, Ventura S. The effect of amyloidogenic peptides on bacterial aging correlates with their intrinsic aggregation propensity. J Mol Biol. 2012:421:270-81.

21. Villar-Piqué A, Ventura S. Modeling amyloids in bacteria. Microb Cell Fact. 2012;11:166.

22. Ami D, Natalello A, Lotti M, Doglia SM. Why and how protein aggregation has to be studied in vivo. Microb Cell Fact. 2013;12:17.

23. Wasmer C, Benkemoun L, Sabaté R, Steinmetz MO, Coulary-Salin B, Wang L, Riek R, Saupe SJ, Meier BH. Solid-state NMR spectroscopy reveals that $E$. coli inclusion bodies of HET-s(218-289) are amyloids. Angew Chem Int Ed Engl. 2009;48:4858-60.

24. Sabaté R, Espargaró A, Saupe SJ, Ventura S. Characterization of the amyloid bacterial inclusion bodies of the HET-s fungal prion. Microb Cell Fact. 2009;8:56

25. Espargaró A, Villar-Piqué A, Sabaté R, Ventura S. Yeast prions form infectious amyloid inclusion bodies in bacteria. Microb Cell Fact. 2012;11:89

26. Garrity SJ, Sivanathan V, Dong J, Lindquist S, Hochschild A. Conversion of a yeast prion protein to an infectious form in bacteria. Proc Natl Acad Sci USA. 2010;107:10596-601.

27. Yuan AH, Garrity SJ, Nako E, Hochschild A. Prion propagation can occur in a prokaryote and requires the CIpB chaperone. Elife. 2014;13:e02949.

28. Wang F, Wang X, Yuan C-G, Ma J. Generating a prion with bacterially expressed recombinant prion protein. Science. 2010;327:1132-5.

29. Villar-Piqué A, Ventura S. Protein aggregation propensity is a crucial determinant of intracellular inclusion formation and quality control degradation. Biochim Biophys Acta Mol Cell Res. 2013;1833:2714-24.

30. Chen SG, Teplow DB, Parchi P, Teller JK, Gambetti P, Autilio-Gambetti L. Truncated forms of the human prion protein in normal brain and in prion diseases. J Biol Chem. 1995;270:19173-80.

31. Jiménez-Huete A, Lievens PM, Vidal R, Piccardo P, Ghetti B, Tagliavini F, Frangione B, Prelli F. Endogenous proteolytic cleavage of normal and disease-associated isoforms of the human prion protein in neural and non-neural tissues. Am J Pathol. 1998;153:1561-72.

32. Altmeppen HC, Puig B, Dohler F, Thurm DK, Falker C, Krasemann S, Glatzel M. Proteolytic processing of the prion protein in health and disease. Am J Neurodegener Dis. 2012;1:15-31.
33. Brown DR, Qin K, Herms JW, Madlung A, Manson J, Strome R, Fraser PE, Kruck T, von Bohlen A, Schulz-Schaeffer W, Giese A, Westaway D, Kretzschmar $\mathrm{H}$. The cellular prion protein binds copper in vivo. Nature. 1997;390:684-7.

34. Caughey B, Brown K, Raymond GJ, Katzenstein GE, Thresher W. Binding of the protease-sensitive form of PrP (prion protein) to sulfated glycosaminoglycan and congo red [corrected]. J Virol. 1994;68:2135-41.

35. Vieira TCRG, Reynaldo DP, Gomes MPB, Almeida MS, Cordeiro Y, Silva JL. Heparin binding by murine recombinant prion protein leads to transient aggregation and formation of rna-resistant species. J Am Chem Soc. 2011;133:334-44.

36. MacEdo B, Millen TA, Braga CACA, Gomes MPB, Ferreira PS, Kraineva J, Winter R, Silva JL, Cordeiro Y. Nonspecific prion protein-nucleic acid interactions lead to different aggregates and cytotoxic species. Biochemistry. 2012;51:5402-13.

37. Chaves JAP, Sanchez-López C, Gomes MPB, Sisnande T, Macedo B, De Oliveira VE, Braga CAC, Rangel LP, Silva JL, Quintanar L, Cordeiro Y. Biophysical and morphological studies on the dual interaction of nonoctarepeat prion protein peptides with copper and nucleic acids. J Biol Inorg Chem. 2014;19:839-51.

38. Critchley P, Kazlauskaite J, Eason R, Pinheiro TJT. Binding of prion proteins to lipid membranes. Biochem Biophys Res Commun. 2004;313:559-67.

39. Linden R, Cordeiro Y, Lima LMTR. Allosteric function and dysfunction of the prion protein. Cell Mol Life Sci. 2012;69:1105-24.

40. Prusiner SB. Novel proteinaceous infectious particles cause scrapie. Science. 1982;216:136-44.

41. Flechsig E, Shmerling D, Hegyi I, Raeber AJ, Fischer M, Cozzio A, von Mering C, Aguzzi A, Weissmann C. Prion protein devoid of the octapeptide repeat region restores susceptibility to scrapie in PrP knockout mice. Neuron. 2000;27:399-408.

42. Fernàndez-Busquets X, de Groot NS, Fernandez D, Ventura S. Recent structural and computational insights into conformational diseases. Curr Med Chem. 2008;15:1336-49.

43. Fink AL. Protein aggregation: folding aggregates, inclusion bodies and amyloid. Fold Design. 1998;3:R9-R23. doi:10.1016/ S1359-0278(98)00002-9.

44. Ami D, Natalello A, Taylor G, Tonon G, Maria Doglia S. Structural analysis of protein inclusion bodies by Fourier transform infrared microspectroscopy. Biochim Biophys Acta. 2006;1764:793-9.

45. Sarroukh R, Goormaghtigh E, Ruysschaert J-M, Raussens V. ATR-FTIR: A "rejuvenated" tool to investigate amyloid proteins. Biochim Biophys Acta Biomembr. 2013;1828:2328-38.

46. Hiramatsu H, Kitagawa T. FT-IR approaches on amyloid fibril structure. Biochim Biophys Acta. 2005;1753:100-7.

47. Byler DM, Susi $\mathrm{H}$. Examination of the secondary structure of proteins by deconvolved FTIR spectra. Biopolymers. 1986;25:469-87.

48. Cordeiro Y, Kraineva J, Ravindra R, Lima LMTR, Gomes MPB, Foguel D, Winter R, Silva JL. Hydration and packing effects on prion folding and $\beta$-sheet conversion: High pressure spectroscopy and pressure perturbation calorimetry studies. J Biol Chem. 2004;279:32354-9.

49. Cordeiro Y, Machado F, Juliano L, Juliano MA, Brentani RR, Foguel D, Silva $J$ L. DNA converts cellular prion protein into the $\beta$-sheet conformation and inhibits prion peptide aggregation. J Biol Chem. 2001;276:49400-9.

50. Gasset M, Baldwin MA, Fletterick RJ, Prusiner SB. Perturbation of the secondary structure of the scrapie prion protein under conditions that alter infectivity. Proc Natl Acad Sci USA. 1993;90:1-5

51. García-Fruitós E, González-Montalbán N, Morell M, Vera A, Ferraz RM, Arís A, Ventura S, Villaverde A. Aggregation as bacterial inclusion bodies does not imply inactivation of enzymes and fluorescent proteins. Microb Cell Fact. 2005;4:27.

52. Carrió M, González-Montalbán N, Vera A, Villaverde A, Ventura S. Amyloidlike properties of bacterial inclusion bodies. J Mol Biol. 2005;347:1025-37.

53. Espargaró A, Sabaté R, Ventura S. Kinetic and thermodynamic stability of bacterial intracellular aggregates. FEBS Lett. 2008;582:3669-73.

54. Sun Y, Breydo L, Makarava N, Yang Q, Bocharova OV, Baskakov IV. Sitespecific conformational studies of prion protein (PrP) amyloid fibrils revealed two cooperative folding domains within amyloid structure. J Biol Chem. 2007;282:9090-7.

55. Espargaró A, Sabate R, Ventura S. Thioflavin-S staining coupled to flow cytometry. A screening tool to detect in vivo protein aggregation. Mol Biosyst. 2012;8:2839. 
56. Pouplana S, Espargaro A, Galdeano C, Viayna E, Sola I, Ventura S, MuñozTorrero D, Sabate R. Thioflavin-S staining of bacterial inclusion bodies for the fast, simple, and inexpensive screening of amyloid aggregation inhibitors. Curr Med Chem. 2014;21:1152-9.

57. Khurana R, Coleman C, lonescu-Zanetti C, Carter SA, Krishna V, Grover RK, Roy R, Singh S. Mechanism of thioflavin T binding to amyloid fibrils. J Struct Biol. 2005;151:229-38.

58. Makarava N, Bocharova OV, Salnikov WV, Breydo L, Anderson M, Baskakov IV. Dichotomous versus palm-type mechanisms of lateral assembly of amyloid fibrils. Protein Sci. 2006;15:1334-41.

59. Baskakov IV, Bocharova OV. In vitro conversion of mammalian prion protein into amyloid fibrils displays unusual features. Biochemistry. 2005:44:2339-48.

60. Anderson M, Bocharova OV, Makarava N, Breydo L, Salnikov W, Baskakov IV. Polymorphism and ultrastructural organization of prion protein amyloid fibrils: an insight from high resolution atomic force microscopy. J Mol Biol. 2006;358:580-96.

61. Liberski PP, Brown P, Xiao SY, Gajdusek DC. The ultrastructural diversity of scrapie-associated fibrils isolated from experimental scrapie and Creutzfeldt-Jakob disease. J Comp Pathol. 1991;105:377-86.

62. Sim VL, Caughey B. Ultrastructures and strain comparison of under-glycosylated scrapie prion fibrils. Neurobiol Aging. 2009;30:2031-42.

63. Jarrett JT, Lansbury PT. Seeding "one-dimensional crystallization" of amyloid: a pathogenic mechanism in Alzheimer's disease and scrapie? Cell. 1993;73:1055-8

64. Caughey B. Prion protein interconversions. Philos Trans R Soc Lond B Biol Sci. 2001;356:197-202.

65. Wickner RB, Taylor KL, Edskes HK, Maddelein ML, Moriyama H, TiborRoberts B. Yeast prions act as genes composed of self-propagating protein amyloids. Adv Protein Chem. 2001;57:313-34.

66. Krebs MRH, Morozova-Roche LA, Daniel K, Robinson CV, Dobson CM. Observation of sequence specificity in the seeding of protein amyloid fibrils. Protein Sci. 2004;13:1933-8.

67. Cordeiro Y, Kraineva J, Gomes MPB, Lopes MH, Martins VR, Lima LMTR, Foguel D, Winter R, Silva JL. The amino-terminal PrP domain is crucial to modulate prion misfolding and aggregation. Biophys J. 2005;89:2667-76.

68. Narang HK. An electron microscopic study of natural scrapie sheep brain: further observations on virus-like particles and paramyxovirus-like tubules. Acta Neuropathol. 1974;28:317-29.

69. Raine CS, Field EJ. Orientated tubules in axoplasm of cerebellar myelinated nerve fibres in the rat. A study of normal and scrapie animals. Acta Neuropathol. 1967;9:298-304.

70. Merz PA, Somerville RA, Wisniewski HM, lqbal K. Abnormal fibrils from scrapie-infected brain. Acta Neuropathol. 1981;54:63-74.

71. Prusiner SB, McKinley MP, Bowman KA, Bolton DC, Bendheim PE, Groth DF, Glenner GG. Scrapie prions aggregate to form amyloid-like birefringent rods. Cell. 1983;35(2 Pt 1):349-58.
72. Deleault NR, Lucassen RW, Supattapone S. RNA molecules stimulate prion protein conversion. Nature. 2003;425:717-20.

73. Gomes MPB, Cordeiro Y, Silva JL. The peculiar interaction between mammalian prion protein and RNA. Prion. 2008;2:64-6.

74. Kocisko DA, Lansbury PT, Caughey B. Partial unfolding and refolding of scrapie-associated prion protein: evidence for a critical 16-kDa C-terminal domain. Biochemistry. 1996;35:13434-42.

75. Saverioni D, Notari S, Capellari S, Poggiolini I, Giese A, Kretzschmar HA, Parchi P. Analyses of protease resistance and aggregation state of abnormal prion protein across the spectrum of human prions. J Biol Chem. 2013;288:27972-85.

76. Caughey B, Raymond GJ, Ernst D, Race RE. N-terminal truncation of the scrapie-associated form of PrP by lysosomal protease(s): implications regarding the site of conversion of PrP to the protease-resistant state. J Virol. 1991;65:6597-603.

77. Nishina K, Jenks S, Supattapone S. lonic strength and transition metals control PrPSc protease resistance and conversion-inducing activity. J Biol Chem. 2004:279:40788-94.

78. Notari S, Capellari S, Giese A, Westner I, Baruzzi A, Ghetti B, Gambetti P, Kretzschmar HA, Parchi P. Effects of different experimental conditions on the PrPSc core generated by protease digestion: implications for strain typing and molecular classification of CJD. J Biol Chem. 2004;279:16797-804.

79. Bocharova OV, Makarava N, Breydo L, Anderson M, Salnikov VV, Baskakov IV. Annealing prion protein amyloid fibrils at high temperature results in extension of a proteinase K-resistant core. J Biol Chem. 2006;281:2373-9.

80. Trevitt CR, Hosszu LLP, Batchelor M, Panico S, Terry C, Nicoll AJ, Risse E, Taylor WA, Sandberg MK, AI-Doujaily H, Linehan JM, Saibil HR, Scott DJ, Collinge J, Waltho JP, Clarke AR. N-terminal domain of prion protein directs its oligomeric association. J Biol Chem. 2014;289:25497-508.

81. Ostapchenko VG, Makarava N, Savtchenko R, Baskakov IV. The polybasic $\mathrm{N}$-terminal region of the prion protein controls the physical properties of both the cellular and fibrillar forms of PrP. J Mol Biol. 2008;383:1210-24.

82. Benetti F, Biarnés X, Attanasio F, Giachin G, Rizzarelli E, Legname G. Structural determinants in prion protein folding and stability. J Mol Biol. 2014;426:3796-810

83. Welker E, Narayan M, Wedemeyer WJ, Scheraga HA. Structural determinants of oxidative folding in proteins. Proc Natl Acad Sci USA. 2001;98:2312-6.

84. Klunk WE, Pettegrew JW, Abraham DJ. Quantitative evaluation of congo red binding to amyloid-like proteins with a beta-pleated sheet conformation. J Histochem Cytochem. 1989;37:1273-81.

85. Colby DW, Wain R, Baskakov IV, Legname G, Palmer CG, Nguyen HOB, Lemus A, Cohen FE, DeArmond SJ, Prusiner SB. Protease-sensitive synthetic prions. PLoS Pathog. 2010;6:e1000736.

\section{Submit your next manuscript to BioMed Central and take full advantage of:}

- Convenient online submission

- Thorough peer review

- No space constraints or color figure charges

- Immediate publication on acceptance

- Inclusion in PubMed, CAS, Scopus and Google Scholar

- Research which is freely available for redistribution

Submit your manuscript at

www.biomedcentral.com/submit
C Biomed Central 